\title{
Bércesi Richárd \\ JAVASLATOK A PÉCSI BÁNYATÖRTÉNETI EMLÉKEK ISKOLAI KERETEK KÖZÖTTI BEMUTATÁSÁRA
}

\begin{abstract}
Absztrakt
Publikációm első felének a témája a pécsi kőszénbányászat történetének a mai ifjúsággal való kapcsolatának az elemzése, kiegészítve a bányászhagyományok helyzetével és a megőrzésükre irányuló törekvésekkel napjainkban. Ehhez kapcsolódva írásom második felében saját óraterveken keresztül teszek javaslatokat az Első Dunagőzhajózási Társaság (a továbbiakban: DGT) által a pécsi bányavidéken 1853 és 1945 között létrehozott, ma is látható emlékeknek a lehetséges bemutatására az iskolai oktatás keretei között.

Több kérdés is foglalkoztatott: Élnek még a bányászhagyományok Pécs városában, és ha igen, akkor mennyire erősek? Van törekvés a megőrzésükre, működnek ilyen célú szervezetek? Részt vesznek a munkájukban az egykori bányásziskolák és a fiatalok? Be lehet vonni a pécsi bányatörténetet az iskolai oktatásba? Ha igen, akkor csak középiskolai szinten, vagy az általános iskolákban is? Kizárólag a történelem tantárgyon keresztül valósítható meg, vagy más jellegű tanórákon is?

Vizsgálataim során a Csorba Győző Könyvtár Helytörténeti Gyűjteményének a szakirodalmát, a helyi sajtóanyagot, valamint az Oktatáskutató és Fejlesztő Intézet (OFI) által kidolgozott, az általános iskolákban és a gimnáziumokban jelenleg is hatályos nemzeti kerettanterveket tekintettem át. Ez mellett oral history alapú interjúkat is készítettem.

Összegezve arra a következtésre jutottam, hogy a DGT és a pécsi kőszénbányászat története jelenleg meglehetősen mellőzött szerepben van, a fiatalok többsége számára a vállalat neve és története jórészt ismeretlen. A még működő Bányászemlékekért Egyesület és az egykori DGT bányásziskolák részéről azonban van törekvés a hagyományok továbbéltetésére és az ifjúság bevonására.
\end{abstract}

Kulcsszavak: DGT pécsi kőszénbányászata; épített örökség; oktatás és hagyományőrzés.

\section{Bevezető}

Az Első Dunagőzhajózási Társaság (a továbbiakban: DGT) 1853-as pécsi megtelepedése sosem látott fejlődést eredményezett a város, valamint az iparág helytörténetében. A kialakulóban lévő bányavidék társadalmának élete, sorsa generációkon át, közel egy évszázadon keresztül, teljes mértékben az itt élő emberek számára a munkát adó vállalattól függött. A cég biztosította a lakhatást, a fütésre szánt feketekőszenet, a szociális juttatásokat, sőt az élelmitárak, és a húsfüstölők révén még egy bizonyos fokig az élelmet is. E mellett a saját tulajdonú elemi és középfokú iskoláiban tanítatta és képezte ki a bányászcsaládok gyerekeit, akik a következő generációként a munkaerő-utánpótlást jelentették az üzemekben (Huszár, 2013). 
A DGT 1945-ös magyarországi kiszorulását követően a pécsi kőszénbányászat más vállalatok (Magyar és Szovjet Hajózási Rt., Pécsi Szén Vállalat, Mecseki Szénbányák, Pécsi Hőerőmű Rt., PannonPower Zrt.) irányítása alatt egészen 2004. december 31-ig tovább működött (Romváry, 2008).

Az iparvidéket alkotó bányászkolóniák zárt világa azonban nem az ágazat teljes felszámolásakor, hanem már korábban, az 1989/1990-es rendszerváltáskor végleg felbomlott, mivel a kommunista éra állami vállalatának, a Mecseki Szénbányák megszűnésével és a „klasszikus” mélyművelésű bányák jelentős részének bezárásával a szakmában dolgozó helyi lakosság nagyobb része kicserélődött, a többiek pedig idős emberekké váltak és nyugdíjba vonultak. A helyükre lépő új alkalmazottak pedig csak elenyésző számban voltak „igazi” tősgyökeres, a kolóniákról származó bányászcsaládok sarjai. Ezért a hátralévő másfél évtizedben hiába működött ugyan (a korábbiakhoz képest jóval kisebb mértékben) a pécsbányatelepi Karolina I.-, és a vasasi Karolina II.-külfejtésekben a szénkitermelés, a bányászélet kezdett egyre inkább a múlttá, emlékké válni (Romváry, 2008).

A bányaművelés megszűnését követően a rekultiváció, valamint az épített örökségek megőrzése és az esetleges új funkció szerinti bemutathatóvá tétele, hasznosítása mellett a legfőbb kérdéssé az vált, hogy miként lehetne a hagyományokat továbbéltetni (Romváry, 2008).

Ez utóbbi témát helyeztem górcső alá a munkámban, amely két részből áll. Publikációm első fele a két helyi bányász hagyományőrző szervezet, a Pécsi Bányásztörténeti Alapítvány (a továbbiakban: PBA), valamint a Bányászemlékekért Egyesület (továbbiakban BEE) működését (különös tekintettel az egykori bányavidéken működő oktatási intézményekkel és rajtuk keresztül a fiatalokkal való kapcsolattartást), céljait, eredményeit és jelenlegi helyzetét mutatja be az oral history alapú interjúkban elhangzott személyes közlések nyomán, valamint az ekkor kapott információknak a helyi sajtóanyag vonatkozó cikkeivel való ütköztetése alapján.

Mivel történészként és pedagógusként is kiemelt fontosságúnak tartom a pécsi helytörténet, azon belül pedig a bányatörténet emlékének az ápolását, ezért írásom második részében két fiktív, általam lemodellezett, hagyományos és kihelyezett tanórát mutatok be, amelynek célja a DGT, valamint a pécsi kőszénbányászat történetének és épített örökségeinek a játékos, ismeretterjesztő, forrásalapú megismertetése az általános és a középiskolás diákokkal.

\section{A DGT és a pécsi kőszénbányászat történetének a lehetséges megjelenési módjai az oktatásban}

Az osztrák-magyar vegyesvállalatként 1829-ben létrehozott DGT (logóját lásd a 22. sz. mellékletben) és az általa világszínvonalúvá emelt pécsi kőszénbányászat (Huszár, 2013) története napjainkban nagyon háttérbe szorított helyzetben van, és leginkább az egykori, ma már nyugdíjas éveiket élő, egyre apadó számú alkalmazottak nosztalgikus, sokszor szomorkás hangvételű beszélgetéseiben éled újjá. A keserűségnek több oka is van. Mun- 
kahelyükből, ami egykor az életüket jelentette, napjainkban már néhány épületen, emléktáblán kívül jóformán semmi sincs, a téma pedig kevésbé fontos kutatási terület a történészek számára1.

Az idősebb generáció szomorúságának azonban nem a kutatók érdeklődésének hiánya a legfőbb kiváltó oka, hanem az, hogy az ifjúság egyre kevesebb hajlandóságot mutat a bányászhagyományok átvétele iránt. A szakmához köthető ünnepeken leginkább csak az egykori dolgozók vesznek részt, míg a leszármazottak egyre kevésbé, vagy sok esetben már egyáltalán nem (Traj, F., személyes közlés, 2017. február 28.).

Véleményem szerint a változáshoz a kulcs egyszerü: meg kell tudni szólítani a fiatalokat a saját nyelvükön, a témát pedig érdekes, kreatív formában kell tálalni számukra. Erre a célra az oktatás és a pedagógia kiváló terep lehetne. Úgy gondolom, hogy a történelem tantárgyon belül kiemelten fontos lenne az, hogy egy középiskolai tanóra keretében a diákság halljon a DGT magyarországi és pécsi történetéről, mivel egy olyan világhírű vállalatról van szó, amely már az 1849 és 1867 közötti időszakban is magában hordozta a dualizmus csíráit, majd Trianon után pedig őrizte annak emlékét (Huszár, 2013). Meglátásom szerint a társaság történetének példáján keresztül a tanulók nemcsak a politika, hanem a gazdaságtörténet mozgatórúgóit is jobban tudnák értelmezni, mintha azt csak és kizárólag a száraz tankönyvi szöveg alapján kellene megtanulniuk.

A témának a diákokkal való megismertetésére további lehetőséget adhatna az általános iskola 5. évfolyamán a Hon-, és népismeret tantárgyon belül a helytörténet (Oktatási Hivatal, n.d.-a), mert a nagyvállalat pécsi megtelepedése és a bányavidék folyamatos fejlesztése, terjeszkedése tette lehetővé annak alapját, hogy a baranyai település az 1900-as évek második felére 160000 fős nagyvárossá fejlődjön (Romváry, 2003). Ezért a tanórákon a római, középkori és a török emlékek bemutatása mellett, kiemelt helyet kellene biztosítani a világhírű vállalat örökségének és az általa létrehozott iparvidék történetének is.

Művészettörténeti szempontból is nagy jelentőségűek a társaság pécsi létesítményei, mivel a XX. század első felében Magyarországon neoklasszicista stílusjegyekkel rendelkező ipari épületek csak és kizárólag itt épültek. A vállalat létesítményeinek egyike sem viseli magán a „magyar történelmi stílus”, vagyis a historizmus jegyeit, hanem megmaradtak annál a neoklasszicizmusnál, amelyet az 1896-os Millennium időszakában pont ez az irányzat szorított ki. A neoklasszicizmusnak a DGT építészetében való továbbélését a társaság osztrák-magyar vegyes tulajdonú vezetése pártfogolta azzal, hogy az első világháború előtt a legtöbbször osztrák tervezőkkel dolgoztak. Ausztriában az első világháborúig ez a művészeti irányzat volt a meghatározó az építészetben (Romváry, 2008).

Az 1920-as évekre, a Bauhaus térhódításával a neoklasszicizmus ugyan fokozatosan visszaszorult, ennek ellenére a vállalatvezetés által felkért, a korábbi osztrák mintát alapul vevő magyar tervezők is ezt a stílust követték tovább, Közép-Európában egyedülálló módon ötvözve az „északi” modernitással, amelyet a legerőteljesebben a svéd licenc alapú vasbeton technika jelenített meg. Ennek legjellemzőbb példái a fehérhegyi víztorony (lásd

${ }^{1}$ Kivéve Huszár Zoltán, Krisztián Béla, Kaposi Zoltán, Majdán János és Pilkhoffer Mónika munkái. 
14. sz. melléklet), a mecsekszabolcsi I. (Szent) István-akna (lásd 15. sz. melléklet), valamint az utóbbival teljesen megegyező, pécsbányatelepi Gróf Széchenyi István-akna (lásd 2-3. sz. mellékletek, 16. sz. melléklet) is (Romváry, 2008).

A DGT pécsi ipari épületeinek egyedi díszítése (Pilkhoffer, 2008) ezért csak tovább növeli a történettudomány szempontjából (is) kiemelt építészeti értéküket (Kéri, 1997), amely jogosulttá tette őket az ipari műemléki védelemre (Szirtes, 2001).

\section{A pécsi bányatörténet és az ifjúság kapcsolata napjainkban}

Az ifjúság megszólítása felé már korábban is történt pozitívnak nevezhető lépés, amely a BEE és személyesen Traj Ferenc tiszteletbeli elnök kezdeményezéséhez köthető („Bányamanók avatása a pécsi Városháza Közgyúlési termében", 2016).

2011 májusában a Budai Városkapu Általános Iskola és Alapfokú Művészeti Iskola meszesi tagiskolájával, valamint a PBA-val való közreműködés eredményeképpen megalakult a Pécsi Bányamanók Mozgalma (lásd 21. sz. melléklet), amelynek minden, második évfolyamtól fölfelé tanuló általános iskolai diák a tagja lehetett. A kezdeményezés sikeres volt, a programhoz az intézmény összes, az egykori pécsi bányavidéken található iskolája csatlakozott (Traj, F., személyes közlés, 2017. február 28.).

A szervezet sok mintát átvett az egykori úttörő, valamint a jelenleg működő cserkészmozgalomból is. Az alapító okirat szerint „a belépéskor a leendő tagoknak esküt kell tenniük a pécsi bányászhagyomány ápolására, a bányászati múlt emlékeinek őrzésére, továbbörökítésére. Mindemellett szabad elhatározásukból tanulmányozzák a pécsi kőszénbányászattal kapcsolatos emlékek történetét, mivel céljuk az, hogy kiemelt tudással rendelkezzenek a pécsi várostörténet egyik legfontosabb epizódjáról, amely a legnagyobb magyarországi városok közé emelte a baranyai települést.” („Bányamanók avatása a pécsi Városháza Közgyülési termében", 2016. p.1.).

2017-ben a mozgalomnak közel 60 tagja volt, és feljebb tudott emelkedni a pusztán helyi szinten működő hagyományőrző szerepből. Először Pécsen belül Uránváros csatlakozott hozzá, és hozta létre saját szervezetét. Ezt követően a pécsi példát több, egykori magyar bányászváros (pl.: Komló, Tatabánya, Miskolc), és maga Budapest is átvette. Traj Ferenc és a BEE kezdeményezése ezzel egy országos szintű szerveződés alapjává vált (Traj, F., személyes közlés, 2017. február 28.).

Első, országos kongresszusukat 2017 májusában, az ötletgazda városban, az egykori pécsi bányavidéken, a Budai Városkapu Általános Iskola és Alapfokú Művészeti Iskola meszesi tagiskolájában tartották. A BEE javaslatára, a jövőbeni tervekkel kapcsolatosan felmerült, hogy a Bányamanók évente ne csak pusztán egy országos találkozót tartsanak valamelyik magyarországi bányavárosban, hanem ott egy vetélkedő formájában is mérjék össze tudásukat, amelynek témája mindig a rendezvénynek az adott évben otthont adó város bányászattal kapcsolatos múltja volt. A pécsi Bányamanók minden városi, az iparághoz köthető a PBA és a BEE által szervezett megemlékezésen, emlékműavatáson, koszorúzáson jelen voltak, ahol képviselték az ifjabb nemzedéket. A korabeli sajtó számára a mozgalomban résztvevő pedagógusok egyöntetűen állították, hogy a diákok szívesen vettek részt a Bányamanók munkájában („Bányamanók avatása a pécsi Városháza Közgyűlési termében”, 2016; „Egyre több bányamanó őrzi a pécsi hagyományokat”, 2016). 
A Budai Városkapu Általános Iskola és Alapfokú Művészeti Iskola meszesi tagiskolájában a bányászmúlt hagyományai szeptember első vasárnapjával összhangban már az évnyitón megjelentek, ahol a Bányamanók műsorának a keretében évente megemlékezést tartottak a pécsi kőszénbányászatról. A hagyományőrzők minden év december 4-ére, Borbála-napra, a bányászat védőszentjének ünnepére is színes műsorral készültek, este pedig a saját maguk által készített lámpásokkal vettek részt a pécsbányatelepi és a mecsekszabolcsi bányászünnepségeken. A tanév során a Bányamanók lényegében szakkörként tevékenykedtek, és rendszeresen (átlagosan egy hónapon belül két alkalommal) tartottak önfejlesztő kurzust. Ez azt jelentette, hogy játékos formában (pl.: rajzolás, képkirakás) ismerkedtek meg a pécsi kőszénbányászat történetével („Egyre több bányamanó őrzi a pécsi hagyományokat", 2016).

A hagyományőrző mozgalom azonban a szervezők fiatalokkal való utánpótlása híján a 2020-as évekre válságba került, mert a benne részt vevő idős bányászok közül időközben sokan elhunytak, a pedagógusok pedig nyugdíjba vonultak. Továbbá a 2020-ban kitörő koronavírus-világjárvány hatásai is negatívan befolyásolták a mozgalmi életet, mivel a Bányamanók működésének létalapját a védekezés során a kormányzat által betiltott közösségi rendezvények adták (Traj, F., személyes közlés, 2021. május 19.). Nemcsak a BEE próbálta közelebb hozni a fiatalokat a bányászmúlthoz. A Pécsbányatelepi Kulturális Központ is szerette volna elérni a bányászhagyományok feltámasztását, mégpedig a két bányásznap családi programmá emelésével. Az elképzelés sarkalatos pontja ezen belül is az új, az 1989-es rendszerváltást követően született generáció számára a pécsi kőszénbányászat örökségeinek a felfedezése olyan formában, amely nem a száraz történelem olvasását, hanem az élményeken alapuló megismerést, a jó hangulatot hordozza magában. Ezért a gyerekek számára kirándulásokat, játékos vetélkedőket, rajzversenyeket szerveztek. Az elképzelésben a PBA és a BEE mellett partnerként megjelent a pécsi Bártfa Utcai Általános Iskola is, amely szintén saját Bányamanó szervezetet működtetett a 2010-es évek végéig (Traj, F., személyes közlés, 2017. február 28.).

A felsorolt példák alapján kijelenthető, hogy törekvés és igény egyaránt volt a pécsi bányászélet, a hagyományok továbbadására. Az elképzelés sikeres lehet akkor, ha valóban kiemelt szerepet kap a kreativitás, mert ezáltal szórakoztató programok szervezésére, új élmények szerzésére is van lehetőség, amely a bányászmúlt iránti fogékonyság táptalajává válhat. Ehhez pedig az oktatás és a közösségi élet nagyon sok segítséget nyújthat a fiatalok számára. A jövő nagy kérdése, hogy a Koronavírus-járvány leküzdése után sikerül-e újjászervezni az e célt szolgáló rendezvényeket, lesz-e még elég közösségteremtő vonzereje a pécsi bányászhagyományoknak.

Az újrakezdést azonban az sem könnyíti meg, hogy a két bányász hagyományőrző egyesület közül a PBA 2019-ben anyagi okok, a tagság elidősödése és a kellő fiatal tagutánpótlás hiánya miatt kénytelen volt beszüntetni a tevékenységét, és feloszlatni magát. Hagyatékuk azonban nem veszett el, mert az általuk őrzött dokumentumokat, relikviákat átadták a Janus Pannonius Múzeum Pécsi Várostörténeti Múzeumának („Megszűnt a Pécsi Bányásztörténeti Alapítvány", 2019). 
Az alapítvány felszámolása egy újabb jelzés afelé, hogyha nem történik meg a nyitás elsősorban a középiskolások, és a már felnőtt, az 1990-es években született generáció irányába, akkor a pécsi bányavidék épített örökségeinek a jelentős része mellett a szellemi értékek is végleg eltűnhetnek, feledésbe merülhetnek.

Az említett korosztályokat a már megszűnt PBA-hoz hasonlóan a még működő BEE sem tudta eddig megszólítani, mivel az egykori „Bányamanók” a középiskolába kerülésüket követően jellemzően már mind eltávolodtak a bányászhagyományok további őrzésétől, az ünnepségeken, rendezvényeken való szerepléstől (Traj, F., személyes közlés, 2021. május 19.).

A folyamat megállításához mindenképpen generáció-, és szemléletmódváltásra lesz szükség, amelybe be kell vonni az egykori pécsi bányásziskolákat és a város középiskoláit is. Véleményem szerint csak és kizárólag ez lehet a kulcsa annak, hogy esély legyen a pécsi bányászhagyományoknak, mint várostörténeti örökségnek a fenntartására.

\section{A DGT és a pécsi bányatörténet ma is látható emlékeinek a lehetséges be- mutatása az iskolai oktatás keretei között}

Írásom korábbi, első fejezetében a felsorolt példákkal arra szerettem volna rámutatni, hogy a DGT-nek a pécsi bányavidéken található örökségei méltóak lehetnének arra, hogy a Történelem, a Hon-, és népismeret, vagy akár a Művészettörténet tantárgyon belül egy fakultációs óra, vagy például az év elejei, őszi tanulmányi kirándulás keretében (Oktatási Hivatal, n.d.-a) bemutatásra kerülhessenek. Sajnálatos módon a tanítási gyakorlataim során ilyen jellegű tanórák tartására nem tudtam sort keríteni, de elképzelésemet a jövőben, immáron gyakorlott pedagógusként mindenképpen szeretném megvalósítani a történelem vagy a hon-, és népismeret órák valamelyikén.

\section{Hagyományos tantermi körülmények között tartott általános iskolai vagy gimnáziumi fakultációs óra terve}

A témával foglalkozó fakultációs, dupla órát kooperatív formában képzelem el (a tanóra tématervtáblázatát lásd az 1. sz. mellékletben). A fakultáción résztvevő diákokat 6 csoportra osztanám fel, spontán szerveződés alapján. A feladat a DGT, valamint az egyes épületek történetének a bemutatása lenne, különös tekintettel a különböző létesítmények által képviselt egyedi ipar-, gazdaság-, közlekedés-, és művészettörténeti értékekre. ${ }^{2}$ Ehhez a vonatkozó szakirodalomból hoznék be szövegrészleteket, továbbá fotókat, újságcikkeket, memoárokat, oral historyn alapuló kiadványokat, amelyek alapján a diákok az épületekkel kapcsolatos legfontosabb információkat rögzítő plakátokat készítenének.

A feldolgozásra és az elkészítésre 20 percet kapnának a tanulók. A rá következő 10 percben a terem különböző részein minden csoport a falra ragasztaná ki a plakátjait, majd sorban, egyesével megnéznék egymás munkáit, amelyekhez komment formájában véleményt írnának (pl.: érthető, nem érthető, hiányos, nem hiányos). A további 10 percben

\footnotetext{
2 1. csoport: A DGT Péccsel kapcsolatos rövid történetének összefoglalása. 2. csoport: A DGT által létrehozott, ideiglenes ipari múemléki védelem alatt álló épületek, 3. csoport: A DGT által létrehozott, egykor ideiglenes ipari múemléki védelem alatt álló, napjainkra már elpusztított ipari létesítmények, 4. A DGT által létrehozott, egykor ideiglenes ipari múemléki védelem alatt álló, jelenleg bontásra váró létesítmények, 5. A DGT által létrehozott, ipari műemléki védelem alá nem vett létesítmények, 6. A DGT által létrehozott, helyi műemléki védelem alá vett létesítmény.
} 
minden csoport nyilvánosan is bemutatná a saját munkáját, valamint reagálna a plakáton lévő esetleges hozzászólásokra. Az óra utolsó öt percében az oktató is nyilvánosan értékelné a csoport munkáját.

A második órán egy, a pécsi kőszénbányászatról szóló filmet (pl.: „Gőzhajó a Dunán”, Rendezte: Somogyvári Rudolf, 2003-2004) vetítenék le a tanulóknak, majd egy totó segítségével mérném le, hogy az első órai csoportmunka, és a filmben látottak alapján mennyi új ismeret maradt meg bennük.

Meglátásom szerint több szempontból is jó lenne, ha egy ilyen jellegű a fakultációs tanóra megvalósításra kerülne. Nem csak azért, mert a diákok plusz információt kapnak az órai törzsanyagból származó ismereteikhez, hanem pedagógiai szempontból sem elhanyagolható, hogy az első órára tervezett, kooperatív csoportmunka keretében a diákoknak több kompetenciája is a közös munka hatására fejlődik.

A második kompetenciának megfelelően ${ }^{3}$, a feladatok kiosztása előtt tanulói csoportok, közösségek kialakulására kerül sor. Mivel a különböző tanulói csoportok nem dolgozhatnak együtt, létrejöhetne az adott közösségeken belüli egymásrautaltság, a csoporttagok egymás iránt tanúsított motiválása, a közös cél (a feladat sikeres végrehajtása), valamint az ebből fakadó esetleges jutalom elérésének a vágya. A diákok érdeke, hogy mindannyian részt vegyenek a munkában, mivel függnek egymástól. A csoportokon belül (a hatodik kompetencia ${ }^{4}$ által meghatározott, tanulási folyamat szervezésének és irányításának megfelelően) mindenkinek saját feladata van (pl.: írnok, időfelelős, szóvivő) amelyre koncentrálnia kell, de ez mellett a munkáját össze kell tudnia hangolni a többiekkel, hogy a tevékenység sikeres lehessen. A hatékonyság záloga ezért a közös, minden csoporttag részvételével zajló munka, amelybe valamilyen formában az inaktív tanulókat is be kell vonni. Ha ez tanári segítség nélkül, a társai által valósul meg, akkor kijelenthető, hogy a csoport tagjai valóban hatékonyan tudnak együtt dolgozni, és pozitív befolyással bírnak egymásra, amely nagyban növeli a siker elérésének lehetőségét is.

A tanulók műveltségének, készségeinek és képességeinek további fejlesztése is megvalósul az által, hogy képi, és szöveges forrásokat értelmeznek, szakirodalmat olvasnak, önállóan, és együttesen gondolkodnak. A megvalósítás során problémákat oldanak meg, társaikat segítik, amely egyrészt a harmadik kompetenciában ${ }^{5}$ foglaltaknak, másrészt az ötödik által megfogalmazott ${ }^{6}$, egész életen át tartó tanulás megalapozásának felel meg.

A diákok a munkafolyamat lezárásaként önmagukat, és egymás munkáját is értékelik, amely a hetedik kompetenciában ${ }^{7}$ rögzített, változatos pedagógiai értékelés megvalósulásának egyik változataként jelenik meg a tanórán.

A felsorolt szempontok alapján ezért összességében úgy vélem, hogy az ilyen jellegű feladatoknak jelentős közösségfejlesztő szerepük van az adott órán részt vevő tanulók számára („Tanári kompetenciák a NyME tanárképzésének értelmezése szerint”, n.d.).

Ez a vágy természetesen egyáltalán nem törvényszerü. A pedagógusnak számolnia kell azzal a ténnyel is, hogy azon tanulók számára, akiknek nem a történelem, vagy a hon-, és

\footnotetext{
3 Tanulói csoportok, közösségek alakulásának segítése, fejlesztése

${ }^{4}$ A tanulási folyamat szervezése és irányítása

${ }^{5}$ A pedagógiai folyamat tervezése

${ }^{6} \mathrm{Az}$ egész életen át tartó tanulást megalapozó kompetenciák hatékony fejlesztése

${ }^{7}$ A pedagógiai értékelés változatos eszközeinek alkalmazása
} 
népismeret a kedvenc tantárgyuk, ettől nem fognak nagyobb érdeklődést szentelni a tananyagnak. Ezért mindenképpen fontosnak tartanám, hogy egy általános iskolai, vagy egy gimnáziumi tanóra keretében egy tanulmányi kirándulást szervezzek az egykori pécsi bányavidékre.

\section{Kihelyezett általános iskolai vagy gimnáziumi tanóra (tanulmányi kirándu- lás) óraterve}

A kihelyezett tanórát jelentő tanulmányi kirándulással a célom az lenne, hogy a tanulók megismerkedjenek a DGT még látható örökségeivel, mivel a tapasztalatszerzés még jobban elősegíti a történelmi tudat kialakulását (Fischerné Dárdai, 2002). Az épületek „mesélő múltként" tárgyi emlékeket képeznek, mivel egy mára már letűnt korszak/korszakok ma is látható tanúi, amellyel közvetítik a történelmet. A tanulók ezt az érzést egy rendes, iskolai tanóra keretében nem tapasztalhatják meg, ezért szükséges, hogy a tanultak kiegészítéseként ellátogassanak a helyszínre, amelyhez az események kötődtek (Kéri, 1997).

Az elképzelés már önmagában jó ötlet lenne abból a szempontból is, hogy a tanulók sokkalta jobban kedvelik a kihelyezett, kirándulással egybekötött tanórákat az átlagos, iskolában tartottakkal szemben. Pedagógiai szempontból pedig a játékos formula hatékony tanulási környezetet jelenthet a tanulók számára, mivel az iskolához hasonlóan, egy ilyen jellegü program során is új ismeretekre tesznek szert (Fischerné Dárdai, 2002).

Komoly problémát jelent azonban a megvalósítás kapcsán az a tény, hogy a helyi mûemléki védelem alatt álló meszespusztai lakótelep (lásd 13. sz. melléklet) és az emléktáblák helyszíneinek (lásd 17-18-19-20. sz. mellékletek) a kivételével, az ideiglenes ipari műemléki védelemmel rendelkező építmények többsége életveszélyes állapotban van, ezért nem látogatható (lásd: 2-3-4-5-6-7-8-9-10-11-12., továbbá a 14-15-16. sz. mellékleteket). A helyzetet úgy oldanám meg, hogy a telekhatáron kívülről tekintenék meg a diákok a létesítményeket. További gondot jelent, hogy a megnézendő emlékek egymástól több kilométeres távolságban vannak, ezért egy ilyen jellegű, kihelyezett tanórán elsősorban Pécsbányatelepre fókuszálnék. Döntésem oka az, hogy a pécsi bányászattörténet múltjára utaló, helyben látható emlék közül a legtöbb ebben a városrészben található meg. További fontos szempont, a gyerekek számára lehetővé szeretném tenni a játékos ismeretszerzést, amelyhez kiváló terep lenne a Pécsbányatelepi Kulturális Ház, amely maga is számos felnőtt, illetve iskolai rendezvénynek szokott otthont adni.

A napot a Gróf Széchenyi István-akna megtekintésével kezdenénk meg. Ehhez a programponthoz a Pécsi Bányászati Múzeumból kérnék fel egy, a témában jártas történészmuzeológust, aki szakszerűen, röviden, és érthetően el tudja mesélni a gyerekek számára a bányaüzem történetét. Széchenyi-akna bemutatása után autóbusszal a Pécsbányatelepi Közösségi Házba mennénk, ahol egy helyismereti vetélkedő szervezésére kerülne sor. A megvalósításban azonban lennének különbségek az általános iskolai, és a gimnáziumi osztályok között.

A játék mindkét esetben három részből állna. Az első részben a spontán módon csapatokba szerveződő tanulók egy 20 kérdésből álló feladatlapot kapnának, majd egy megadott útvonalon kellene felkeresniük a kolónia legjelentősebb emlékeit (pl.: köztéri szobrok, emléktáblák, épületek). A feladat az lenne, hogy a helyszínen fellelhető információk 
(pl.: szobor, vagy emléktábla felirata) segítségével kell megválaszolniuk a lapon szereplő kérdéseket ${ }^{8}$, kiegészíteni a hiányos mondatokat ${ }^{9}$, vagy három választási lehetőség közül kiválasztani a helyes választ ${ }^{10}$. Mindhárom verzió szerepelne a vegyes típusú feladatok között. Segítségül mindössze egy térképet kapnának a kijelölt útvonalról, amelyet a feladatlapon szereplő egyértelmű utalások alapján kellene bejárniuk. A játék ideje kb. 60 perc lenne. Ezt követően a diákok a feladatlapjaikat a kultúrházban kialakított célállomáson adnák le. Az elérhető maximum pontszám 20 pont lenne, és mindenki az alapján kapná a pontokat, ahány kérdésre helyesen tudott válaszolni. Minden jó megoldás egy pontot érne.

Az általános iskolások esetében a következő programpont egy igaz-hamis játék lenne, amely során 10+1 állítást olvasnék fel Pécsbányatelep történetéről. A diákoknak pedig helyváltoztatással kellene eldönteniük, hogy az általam tett kijelentések igazak vagy hamisak $^{11}$. A feladat során a megszerezhető maximum pontszám 10 pont lenne, a bónusz állítás helyes megválaszolásával pedig 1 többletpontot, vagy esetleg egy korábbi téves válasz esetén otthagyott pontot lehetne „visszarabolni”. A játék kb. 30 percig tartana.

A nap zárásaként, az utolsó feladat a puzzle-módszeren alapulna. Több ismert pécsbányatelepi bányászemlék, vagy épület képét szétdarabolnám, a gyerekek feladata pedig a kirakásuk lenne. A helyes megoldás itt is 10 pontot érne.

Egy gimnáziumi osztály esetében, második feladatként, a kultúrházban levetítenénk egy 15 perces dokumentumfilmet („1 csepp Pécs: Az Első Dunagőzhajózási Társaság pécsi emlékhelyei", Pécs Tv, 2005.). A megtekintés után 10+1 állítást olvasnék fel nekik a filmben látottakkal kapcsolatosan, amelyekről el kellene dönteniük, hogy igaz, vagy hamis. Igaz válasz esetén a kezük felrakásával kellene kifejezniük a véleményüket. A feladat azonban nem lenne könnyű, mivel menet közben az egyes csapatok két rossz válaszadása esetén kiesnének a játékból. Az első rossz válasz még csak „veszélyeztetetté” tenné a csapatot, a második után azonban már nem vehetnének részt a folytatásban. A már nem szereplő tanulók elhagynák a helységet, és a folyosón várakoznának társaikra. Abban az esetben, ha idő előtt már csak egy csoport maradna versenyben, a játék véget ér, és megkapnák a maximum pontot. A korábban kiesett csapatok annyi pontot szereznének, ahány kérdést sikerrel megválaszoltak.

A harmadik feladatban a diákoknak egy keresztrejtvényt kellene megoldaniuk, amely az aznap látottakkal kapcsolatos feladványokat tartalmazná. A feladat helyes megoldásáért 10 pont járna. Abban az esetben, ha nem sikerülne hibátlanul megoldaniuk, annyi pontot kapnának, ahány megoldás helyes volt.

A vetélkedőt az általános, és a gimnáziumi osztály esetében is az a csapat nyerné, amelyik a legtöbb pontot szerzi meg a három feladatból. A jutalmazás módszeréhez folyamodva, órai munkáért adott jeles érdemjeggyel honorálnám az első helyen végző csapatot/csapatokat. A többiek sem távoznának üres kézzel, ők négyes osztályzatot kapnának, de csak akkor, ha kérik a jegyet.

\footnotetext{
${ }^{8} \mathrm{Pl}$ : Kiről nevezték el Pécsbányatelep ma is álló aknatornyát? Gróf Széchenyi Istvánról, akinek neve az épületen olvasható.

${ }^{9} \mathrm{Pl}$ : : Az 1968-as vízbeömlés emlékére. A feladat az évszám kipótlása lenne.

${ }^{10} \mathrm{Pl}$.: A velünk szemben látható épülettömb milyen funkciót látott el? A, Közösségi ház. B, Tűzoltóság. C, Kórház. D, Iskola. A helyes válasz a C. Ok: Az épület főhomlokzatán ez a felirat látható.

${ }^{11} \mathrm{Pl}$.: egy lábon szökdelés, ha a diák véleménye szerint az állítás igaz, vagy guggolnia kell, ha szerinte a kijelentés helytelen.
} 
Véleményem szerint ez a kihelyezett óra nemcsak a bányászemlékek testközelből való megismerése kapcsán, hanem pedagógiai szempontból is kifejezetten hasznos lenne, mivel a kooperatív csoportmunka keretében a diákok kompetenciái a közös munka hatására fejlődhetnének. A tanulók gyakorolhatnák a képi és szöveges források értelmezését, az önálló és együttes gondolkodást, problémamegoldást, valamint egymás segítését. Mivel egymásrautaltság és közös cél (a feladat sikeres végrehajtása), továbbá az ebből fakadó esetleges jutalom elérésének a vágya alakulna ki, a csoporttagok kölcsönösen motiválnák egymást, hiszen érdekük lenne, hogy mindannyian részt vegyenek a munkában. A hatékonyság záloga ezért a közös, minden csoporttag részvételével zajló munka, amelybe valamilyen formában az inaktív tanulókat is be kell vonni. Ha ez tanári segítség nélkül, a társak által valósul meg, akkor kijelenthető, hogy a csoport tagjai valóban hatékonyan tudnak együtt dolgozni és pozitív befolyással bírnak egymásra, amely nagyban növeli a siker elérésének lehetőségét is („Tanári kompetenciák a NyME tanárképzésének értelmezése szerint", n.d.).

Úgy vélem, hogy az ilyen jellegű feladatoknak közösségfejlesztő szerepük is van. A kihelyezett óra esetében fontos szempont, hogy a diákok későbbi tanulmányaik során tudják kamatoztatni az itt megszerzett ismereteiket, és számos, jó élménnyel is gazdagodjanak („Tanári kompetenciák a NyME tanárképzésének értelmezése szerint”, n.d.).

\section{Összegzés}

A DGT 92 évig meghatározó szereplője volt Magyarország gazdaságtörténetének, és azon belül Pécs város helytörténetének, mivel a szénbányák fokozatos megnyitásával párhuzamosan törekedett a kialakulóban lévő iparvidék folyamatos fejlesztésére is. A kiváló tervezőmunkáknak köszönhetően üzemépületei nemcsak egyedülállóak voltak a maguk korában, hanem világszínvonalúak is, ahol szigorúan ellenőrzött, szakszerű termelés folyt.

Az ipar és a gazdaságtörténet mellett azonban fontos kiemelni, hogy a DGT kulturálisszellemi téren is nagy sikereket ért el azzal, hogy az általa működtetett iskolák révén nagy hangsúlyt helyezett a bányászidentitás megteremtésére, amelyet a kolóniák társadalma a társaság 1945-ös magyarországi megszűnése után is egészen az 1989/1990-es rendszerváltásig őrzött, és továbbörökített a soron következő generációk számára. A Mecseki Szénbányák állami vállalat 1991-es felszámolása (Szirtes, 1993), a pécsi bányavidék lakosságának fokozatos kicserélődése, valamint az egykori alkalmazottak elöregedése és halála azonban kérdésessé tette a „bányászmúlt”, és a hagyományok továbbélését, aminek a megmentésére és az ápolására jött létre az idős tagokból álló és a jelenleg utánpótlás nélkül álló BEE, valamint a mára már meg is szűnt PBA („Megszűnt a Pécsi Bányásztörténeti Alapítvány", 2019).

Véleményem szerint, ha a fiatalság számára az oktatáson keresztül (pl.: történelem, hon-, és népismeret, földrajz, művészettörténet tantárgyakon belül, akár kihelyezett szabadtéri tanórákon is) nem adunk lehetőséget a DGT és a pécsi bányavidék örökségének a megismertetésére (a Bányamanók szervezete e célból jött létre az egykori bányásziskolákban), akkor a város helytörténetének egyik legfontosabb szellemi-kulturális értékére az elfeledés, a használaton kívüli ipari épületekre pedig a bontás vár. A hagyományőrző 
célzattal szervezett bányásznapi programok, rendezvények hiányából fakadó érdektelenség ugyanezzel a végkifejlettel járhat, aminek egyik következménye és állomása volt a PBA kényszerű felszámolása is.

Ha ez bekövetkezik, akkor az utókor csak a régi könyvek megsárgult lapjairól, vagy a korabeli fényképek alapján fog esetleg tudni arról, hogy volt egyszer egy világhírű vállalat, amely amellett, hogy világszínvonalú ipari üzemi egységeket, modern épületekből álló városrészeket hozott létre és az egyik legnagyobb vidéki nagyvárossá tette a Mecsek lábánál elterülő Pécset, az önálló, zárt világot alkotó kolóniák társadalmának identitásfejlődését is nagyban segítette. Ezért az emlékek megőrzése és örökség védelme közös feladatunk, hogy a DGT által elért eredmények ne tűnjenek el nyomtalanul a jövőben.

\section{Irodalomjegyzék}

Bányamanók avatása a pécsi Városháza Közgyülési termében (2016. szeptember 30.). Új Dunántúli Napló, 1.

Egyre több bányamanó őrzi a pécsi hagyományokat (2016. szeptember 30.). Pécsi Hírek, 5.

Fischerné Dárdai, Á. (2002). Történelemdidaktika és kontroverzív történelemtanítás. In: Nagy, P. T. \& Vargyai, Gy. (szerk.), Történelem tanítás módszertan: Tanulmányok a 75 éves

Szabolcs Ottó tiszteletére (pp.34-43). Országos Pedagógiai Könyvtár és Múzeum.

Huszár, Z. (2013). A Duna vonzásában. Fejezetek a Dunagőzhajózási Társaság történetéből. Válogatott tanulmányok. Virágmandula Kft.

Kéri, K. (1997). Mi a neveléstörténet? A diszciplina múltja, jelene, és jövője. In: Kéri K. (Eds.), Mozaikok a nevelés történetéből II. (pp. 13-33). Janus Pannonius Tudományegyetem, Tanárképző Intézet.

Megszűnt a Pécsi Bányásztörténeti Alapítvány (2019. június 25.). Pécsi Napilap. Letöltés dátuma: http://m.pecsinapilap.hu/cikk/Megszunt_a_Pecsi_Banyasztorteneti_Alapitvany/223539

Pilkhoffer, M. (2008). Bányászat és építészet Pécsett a 19-20. században. Pécsi Bányásztörténeti Alapítvány - Pro Pannonia Kiadói Alapítvány.

Oktatási Hivatal (n.d.-a). Kerettanterv az általános iskola 5-8. évfolyama számára. Letöltés dátuma: 2021. december 27.

Oktatási Hivatal (n.d.-b). Kerettanterv a gimnáziumok 9-12. évfolyama számára. Letöltés dátuma: 2021. december 27.

Romváry, F. (szerk.). (2003). Emléklapok a pécsi bányászat történetéből. Bocz Nyomdaipari Kft. Romváry, F. (szerk.). (2008). Újabb emléklapok a pécsi bányászat történetéből. Bocz Nyomdaipari Kft. Szirtes, B. (szerk.). (1993). A mecseki kőszénbányászat 1945-1991. I. kötet. Kútforrás Kft. Szirtes, B. (2001). Unokáink is látni fogják? Pécsi Szemle Várostörténeti Folyóirat, IV (3), 104-109. Tanári kompetenciák a NyME tanárképzésének értelmezése szerint (n.d.). https://www2.itworx.hu/cgibin/itworx/download.cgi?vid=606\&uid=-1\&dokid=330 Letöltés dátuma: 2017 . június 3. 


\section{Mellékletek}

\section{1. sz. melléklet: Az Első Dunagőzhajózási Társaság (DGT) épített örökségeit górcső}

\section{alá helyező fakultációs tanóra tématervtáblázata. (Forrás: saját forrás)}

Osztály: 7-8. és 11-12. évfolyam

Tantárgy: Történelem, Hon-, és népismeret.

Modul: A, Történelem: Magyarország gazdaságtörténete a XIX. század második (1853-1867,1867-1914), és a XX. század első felében (1920-1945),

B, Honismeret: Az én világom II. (Helytörténet)

Téma: Az Első Dunagőzhajózási Társaság épített örökségei Pécsen (Fakultációs óra, 2X45 perc)

Célok: Pécs XIX.-XX. századi helytörténetének, és azon belül az Első Dunagőzhajózási Társaságnak az egykori bányavidéken fellelhető, ideiglenes ipari műemléki védelem alá helyezett, és az alól kimaradt épített örökségeinek a megismerése

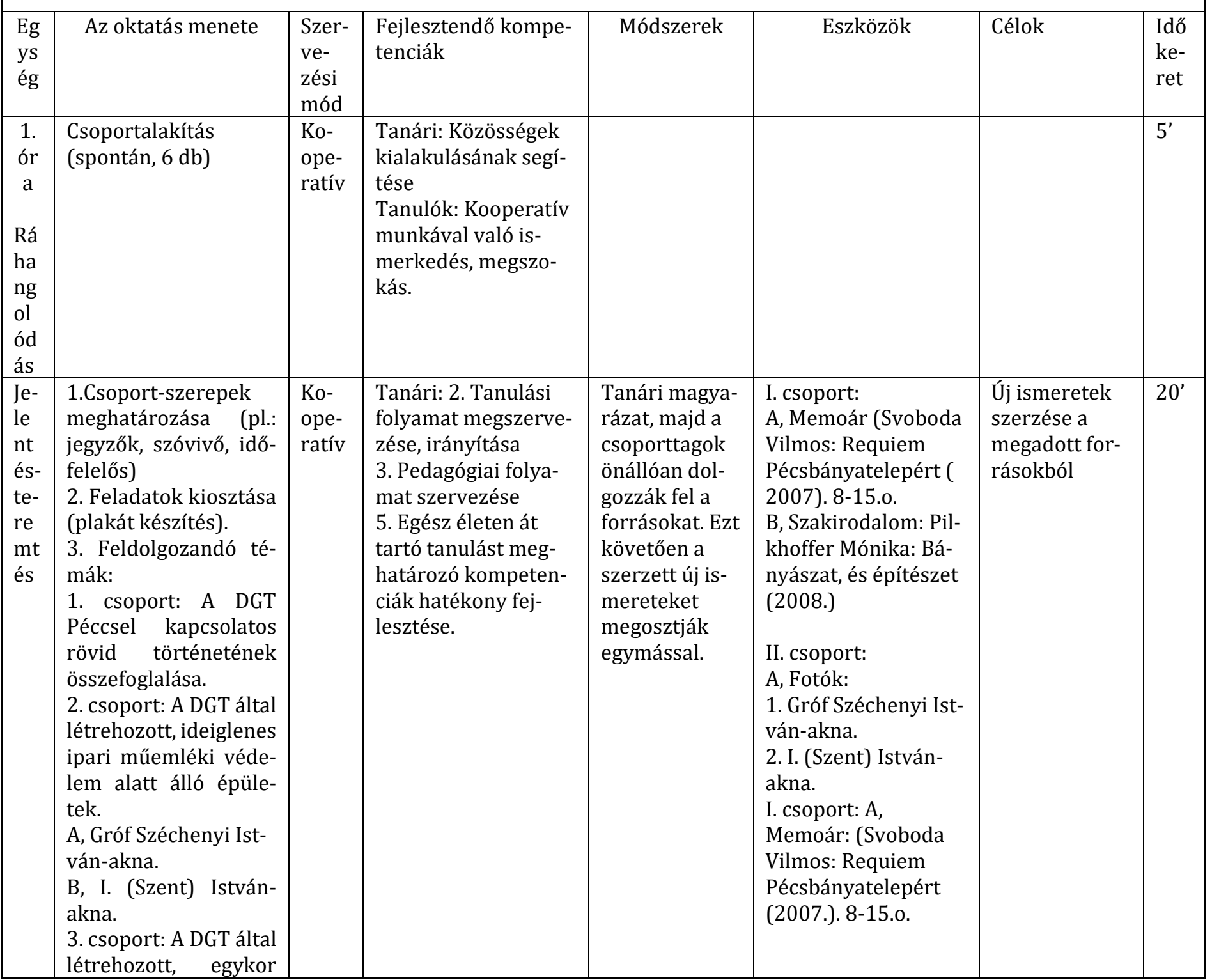




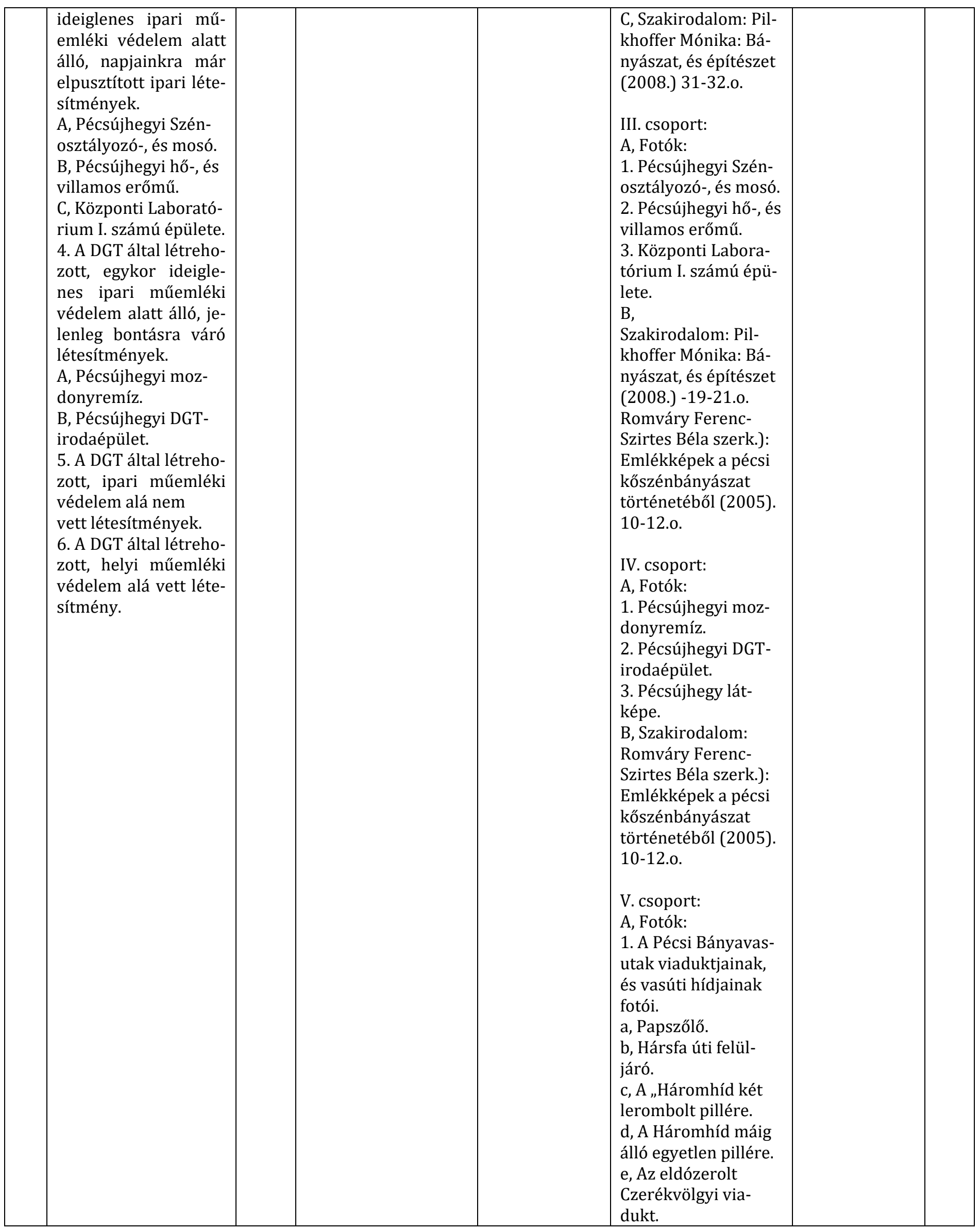




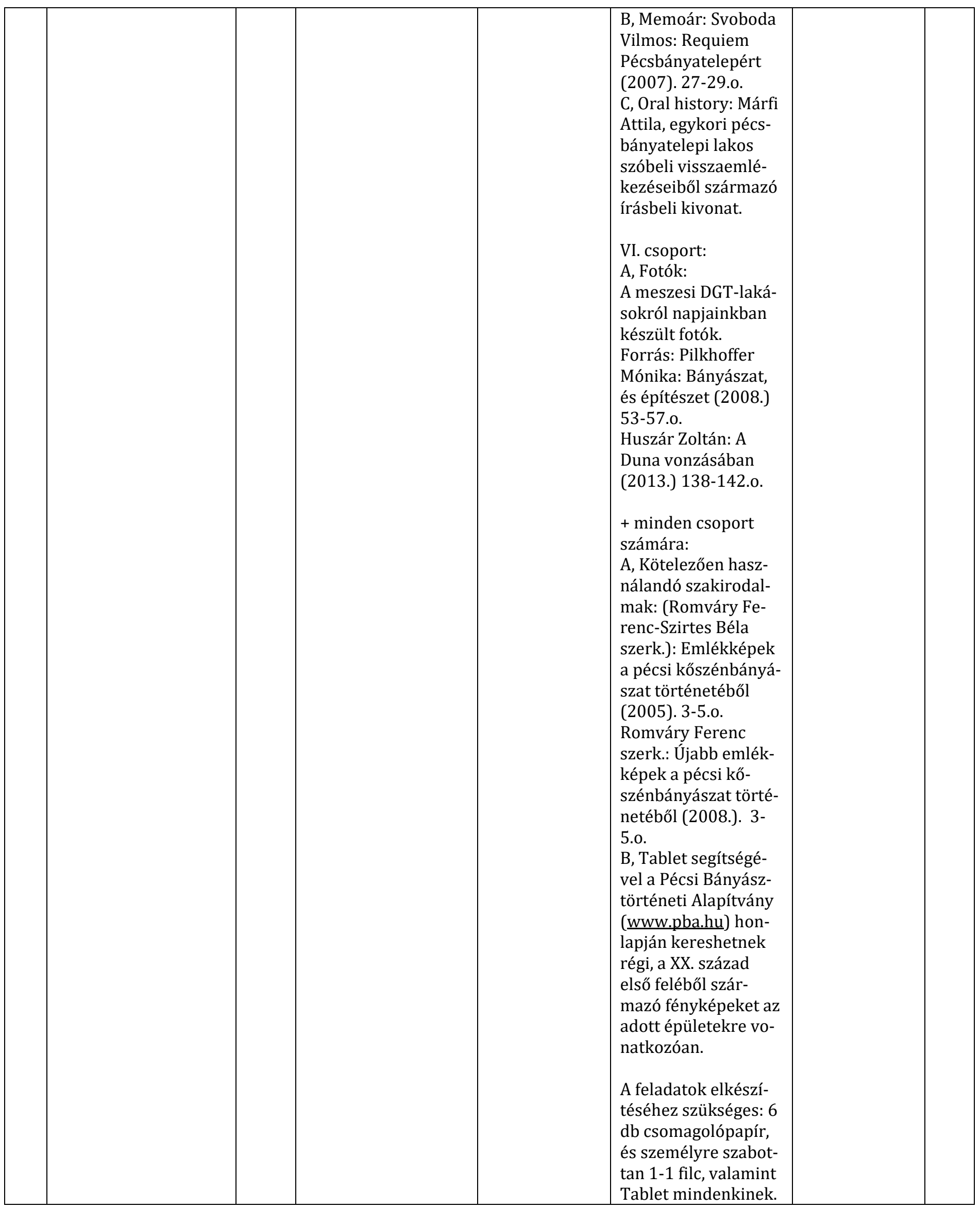




\begin{tabular}{|c|c|c|c|c|c|c|}
\hline & $\begin{array}{l}\text { Az elkészítés után a } \\
\text { csoportok kiragaszt- } \\
\text { ják a plakátjaikat tan- } \\
\text { teremben. } \\
\text { A csoportok megte- } \\
\text { kintik egymás mun- } \\
\text { káját, amelyhez véle- } \\
\text { ményt, kommentet ír- } \\
\text { nak. }\end{array}$ & $\begin{array}{l}\text { Ko- } \\
\text { ope- } \\
\text { ratív }\end{array}$ & $\begin{array}{l}\text { Tanári: } \\
\text { 7. A Pedagógiai érté- } \\
\text { kelés változatos } \\
\text { módszereinek az al- } \\
\text { kalmazása. } \\
\text { Tanulók: Kritikai } \\
\text { szemléletmód kiala- } \\
\text { kulásának elősegí- } \\
\text { tése. }\end{array}$ & & $\begin{array}{l}\text { További új is- } \\
\text { meretek szer- } \\
\text { zése } \\
\text { Egymás érté- } \\
\text { kelésének a } \\
\text { gyakorlása. }\end{array}$ & $10^{\prime}$ \\
\hline & $\begin{array}{l}\text { Minden csoport be- } \\
\text { mutatja a saját mun- } \\
\text { káját, majd reagál a } \\
\text { plakátra írt kommen- } \\
\text { tekre. }\end{array}$ & $\begin{array}{l}\text { Pro- } \\
\text { jekt }\end{array}$ & $\begin{array}{l}\text { Önkifejezés, előadás- } \\
\text { mód fejlesztése. }\end{array}$ & & $\begin{array}{l}\text { Érvelés gya- } \\
\text { korlása }\end{array}$ & $10^{\prime}$ \\
\hline & Oktatói értékelés. & & $\begin{array}{l}\text { Tanári: } \\
\text { 7. A Pedagógiai érté- } \\
\text { kelés változatos } \\
\text { módszereinek az al- } \\
\text { kalmazása. }\end{array}$ & & & $5^{\prime}$ \\
\hline $\begin{array}{l}2 . o ́ \\
\text { ra }\end{array}$ & $\begin{array}{l}\text { „Gőzhajó a Dunán” } \\
\text { című film levetítése. }\end{array}$ & $\begin{array}{l}\text { Szem } \\
\text { lélte- } \\
\text { tés }\end{array}$ & Forráshasználat & $\begin{array}{l}\text { Laptop, Projektor, } \\
\text { DVD }\end{array}$ & $\begin{array}{l}\text { Az új ismere- } \\
\text { tek kiegészí- } \\
\text { tése,rögzítése. } \\
\text { A dokumen- } \\
\text { tumfilm, mint } \\
\text { forrás megis- } \\
\text { merése, hasz- } \\
\text { nálata. }\end{array}$ & $40^{\prime}$ \\
\hline $\begin{array}{l}\text { Re } \\
\text { fle } \\
\text { kt } \\
\text { álá } \\
\text { s }\end{array}$ & Totó & $\begin{array}{l}\text { Egyé } \\
\text { ni }\end{array}$ & & & $\begin{array}{l}\text { A szerzett is- } \\
\text { meretek leel- } \\
\text { lenőrzése. }\end{array}$ & $5^{\prime}$ \\
\hline
\end{tabular}

2. sz. melléklet: Schroll (Széchenyi-)-akna széntároló silója a II. számú Ganz-villanymozdonnyal, miközben a Talbot-vagonok töltése zajlik

Pécsbányatelep, Gróf Széchenyi István-akna, vasútállomás

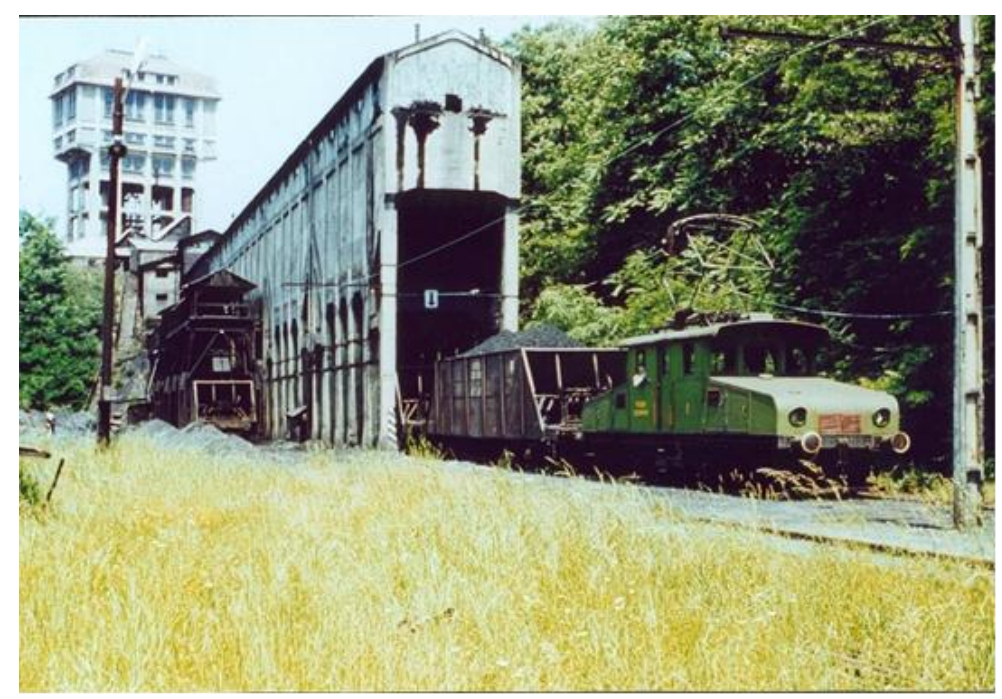

Fotó: Lakos Rudolf, 1978. Lakos Rudolf magángyüjteménye 
3. sz. melléklet: Schroll (Széchenyi-)-akna széntároló silója a Dacia-dízelmozdonnyal, miközben a MÁV-vagonok töltése zajlik

Pécsbányatelep, Gróf Széchenyi István-akna, vasútállomás

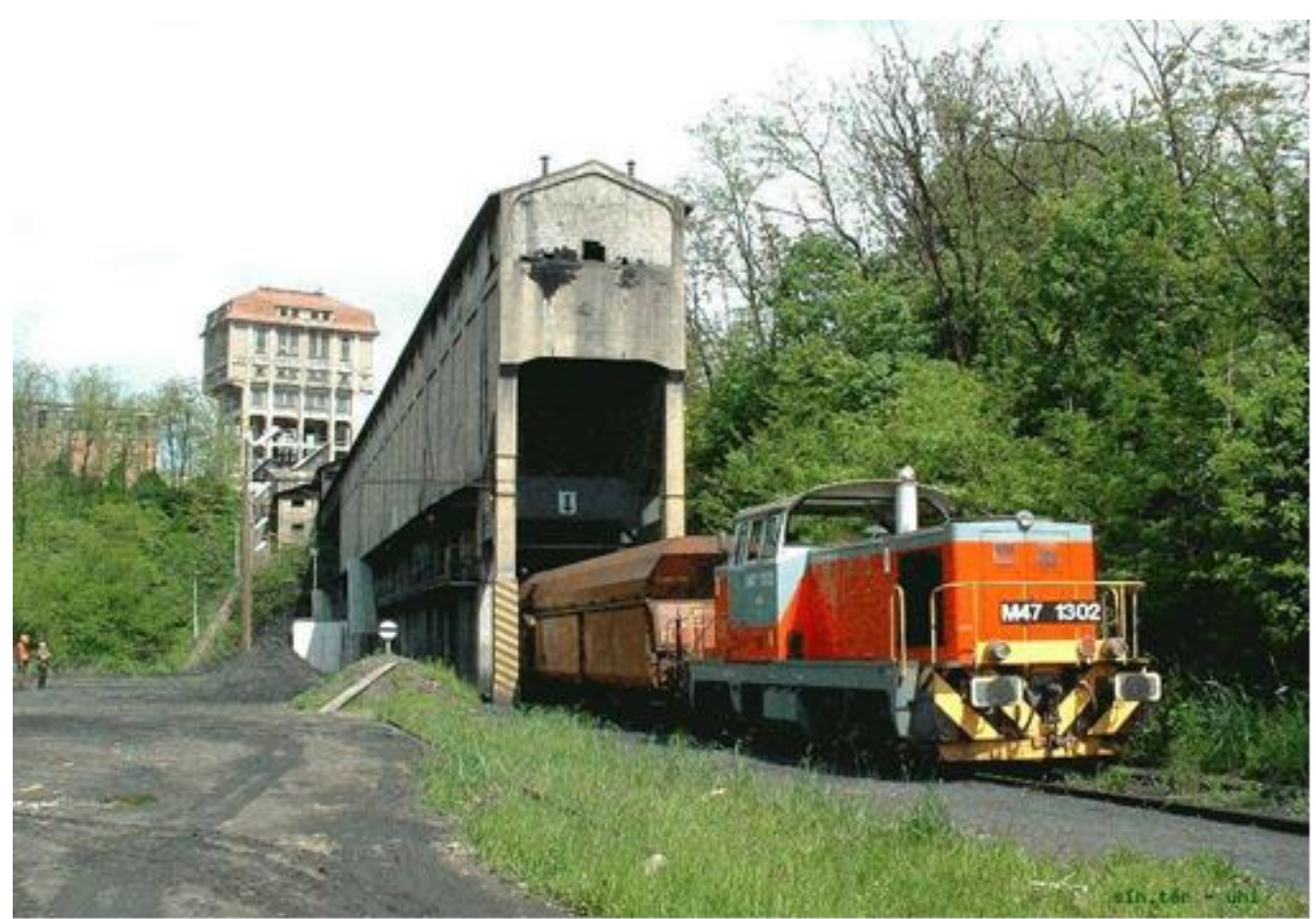

Fotó: Uherkovich Péter, 2004. Uherkovich Péter magángyüjteménye

\section{Sz. melléklet: A megszüntetett vasútállomás Gróf Széchenyi István-aknán}

Pécsbányatelep, Gróf Széchenyi István-akna, vasútállomás

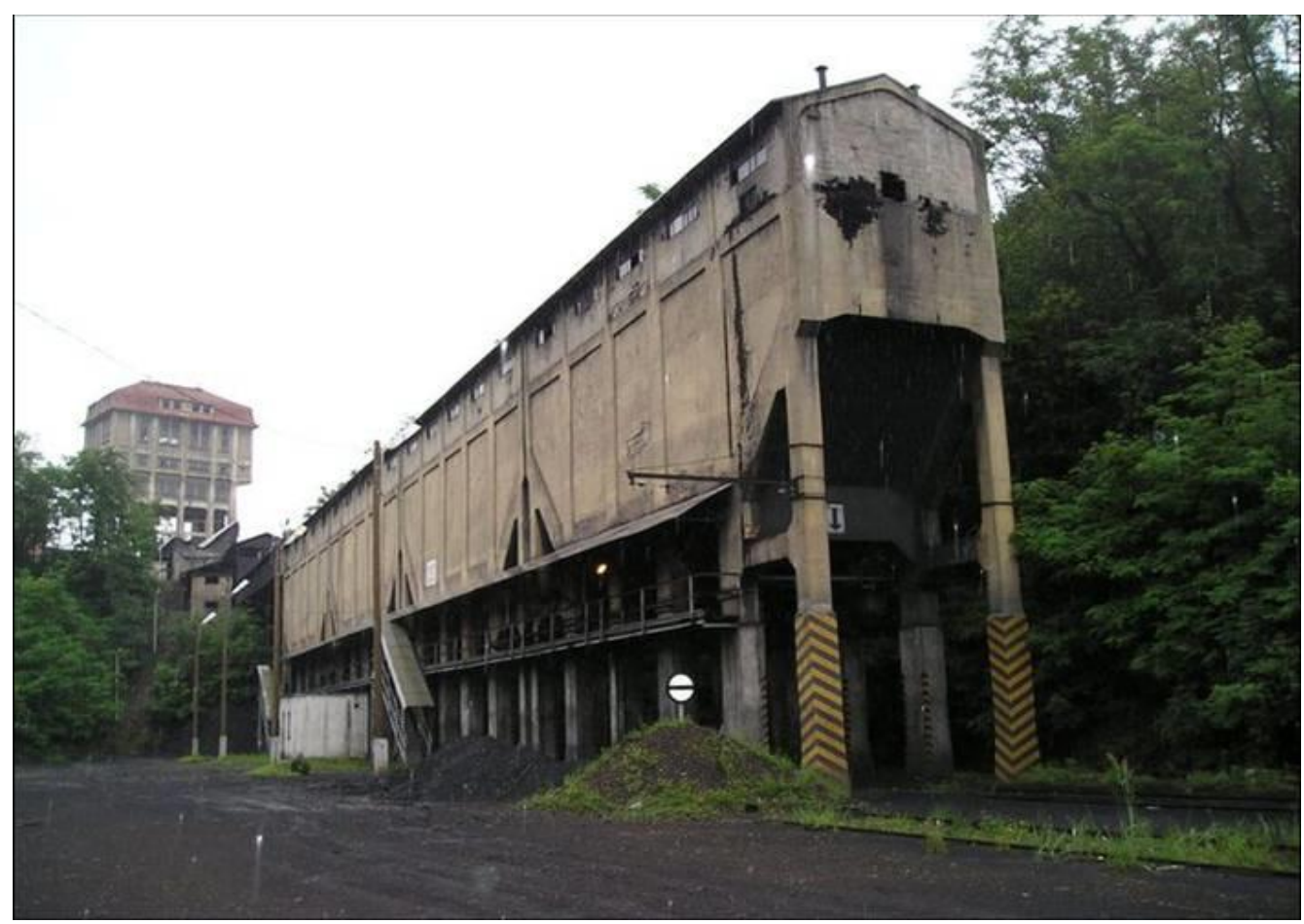

Fotó: Uherkovich Péter, 2004. Uherkovich Péter magángyűjteménye 
5. sz. melléklet: A Pécsi Bányavasutak Pécsbányatelepi vonalához tartozó, még álló, egypillérü viaduktja (1854-) az egykori Papszőlőben

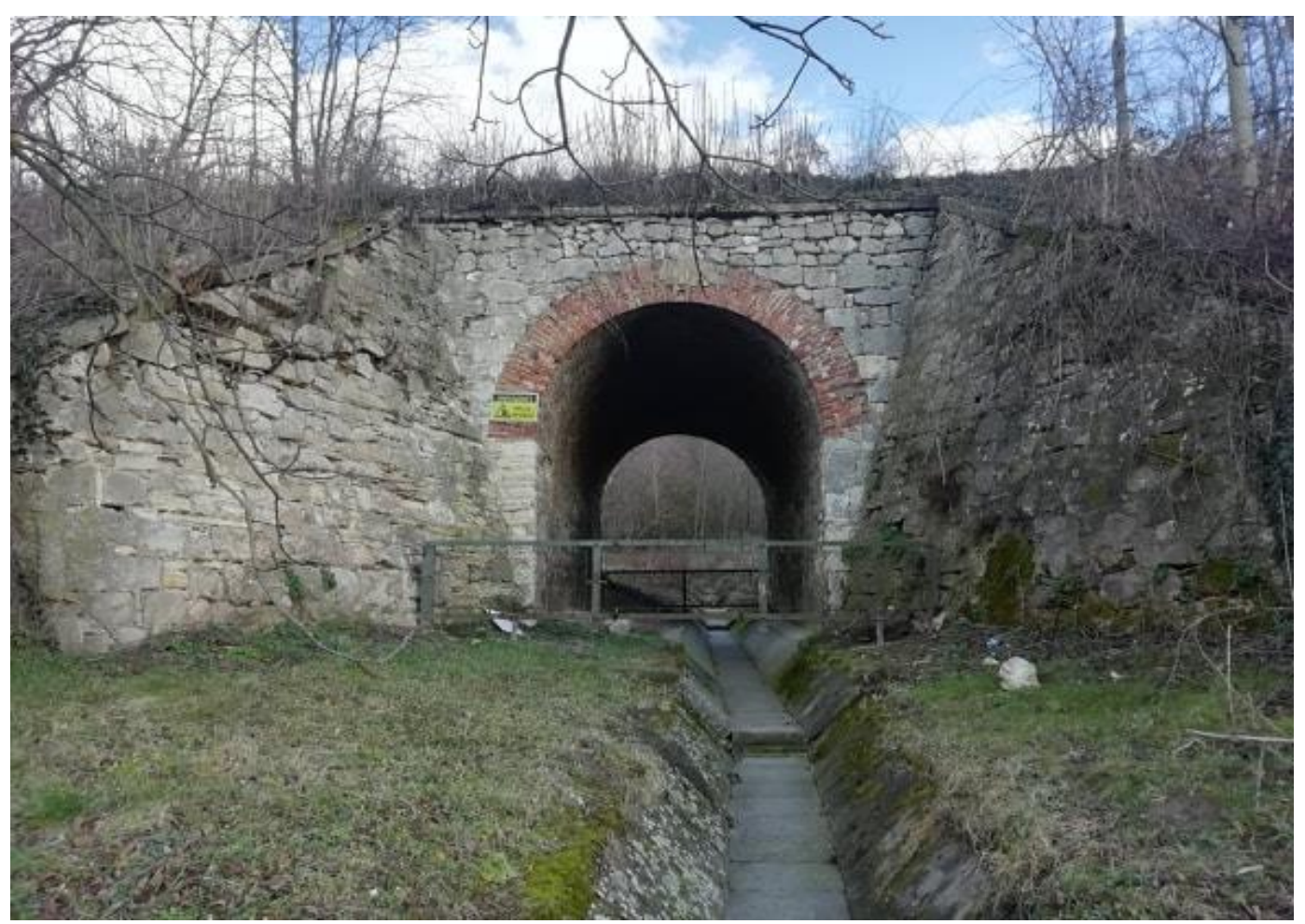

Fotó: Bércesi Richárd, 2020.

6. sz. melléklet: A „Háromhíd” felrobbantott két pillérének maradványai (18541971)

Bánom, Pécsbányatelepi vasút, András-akna iparvágány

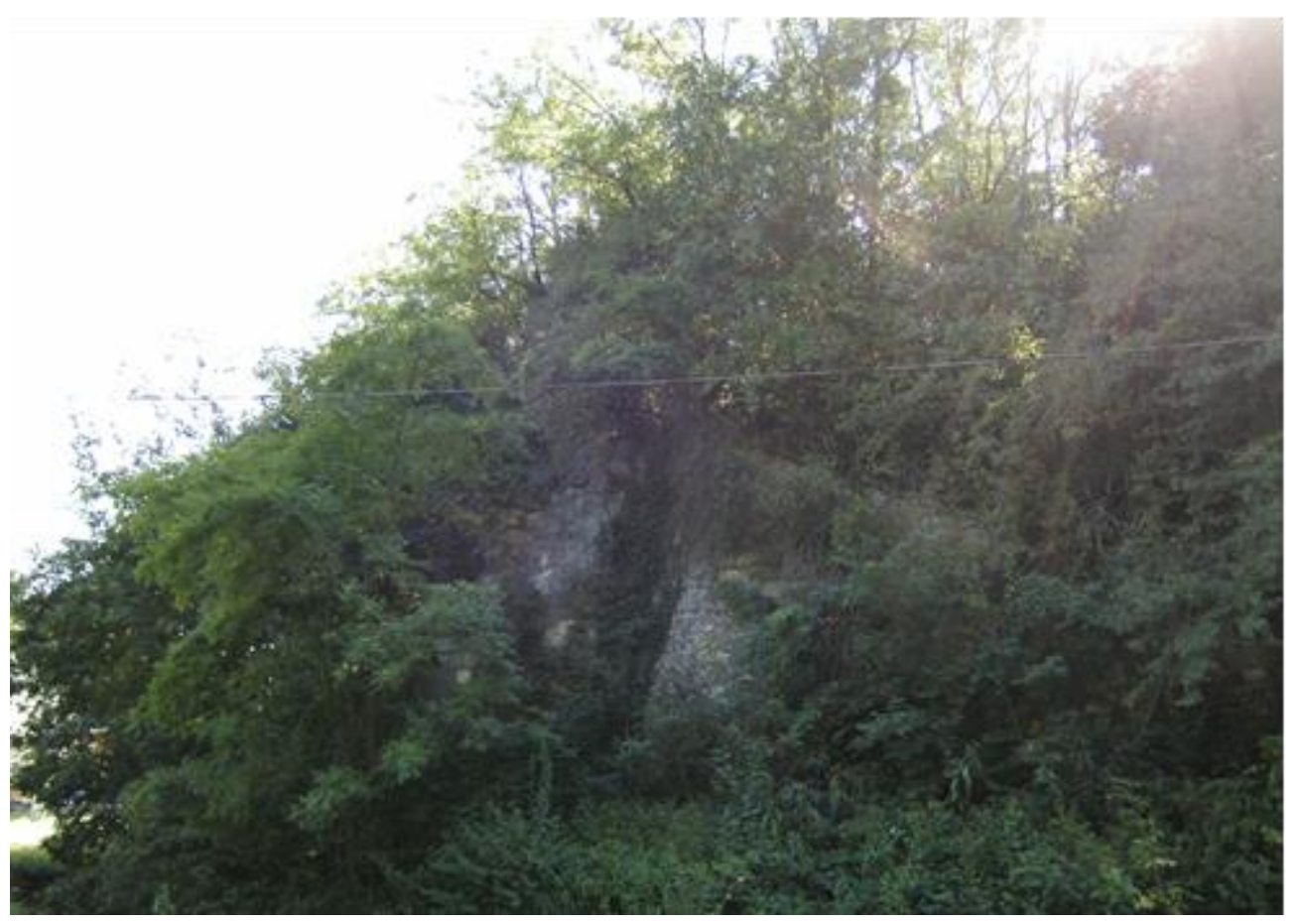

Fotó: Bércesi Richárd, 2011. 
7. sz. melléklet: A „Háromhíd” egyetlen, napjainkra megmaradt, teljesen ép pillére

Bánom, Pécsi Bányavasutak, Pécsbányatelepi vasút, Széchenyi-akna iparvágány

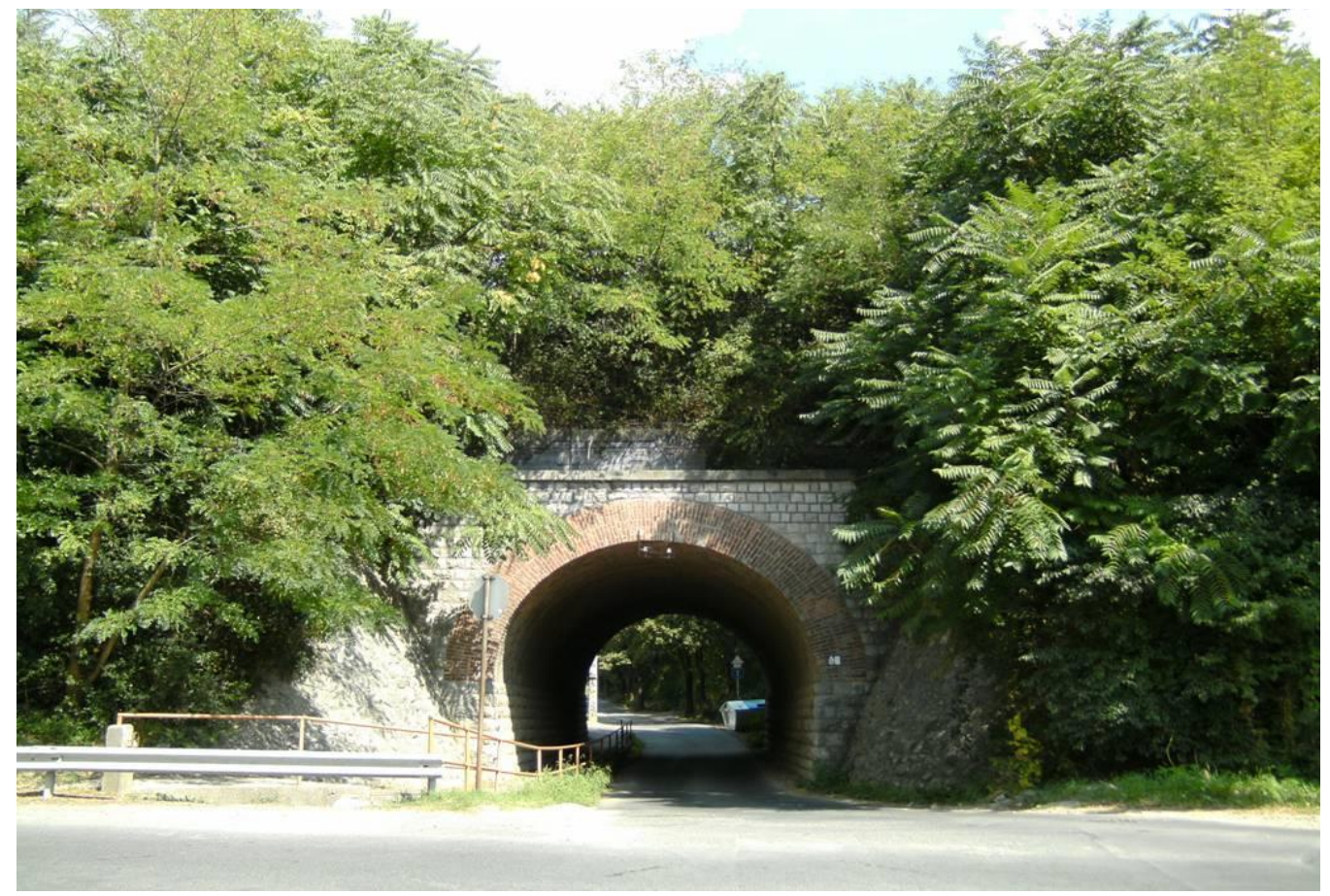

Fotó: Bércesi Richárd, 2011.

8. sz. melléklet: A Pécsi Bányavasutak Pécsbányatelepi vonalához tartozó, 1925ben elbontott viaduktjának helyére épített vashíd napjainkban

Hársfa út

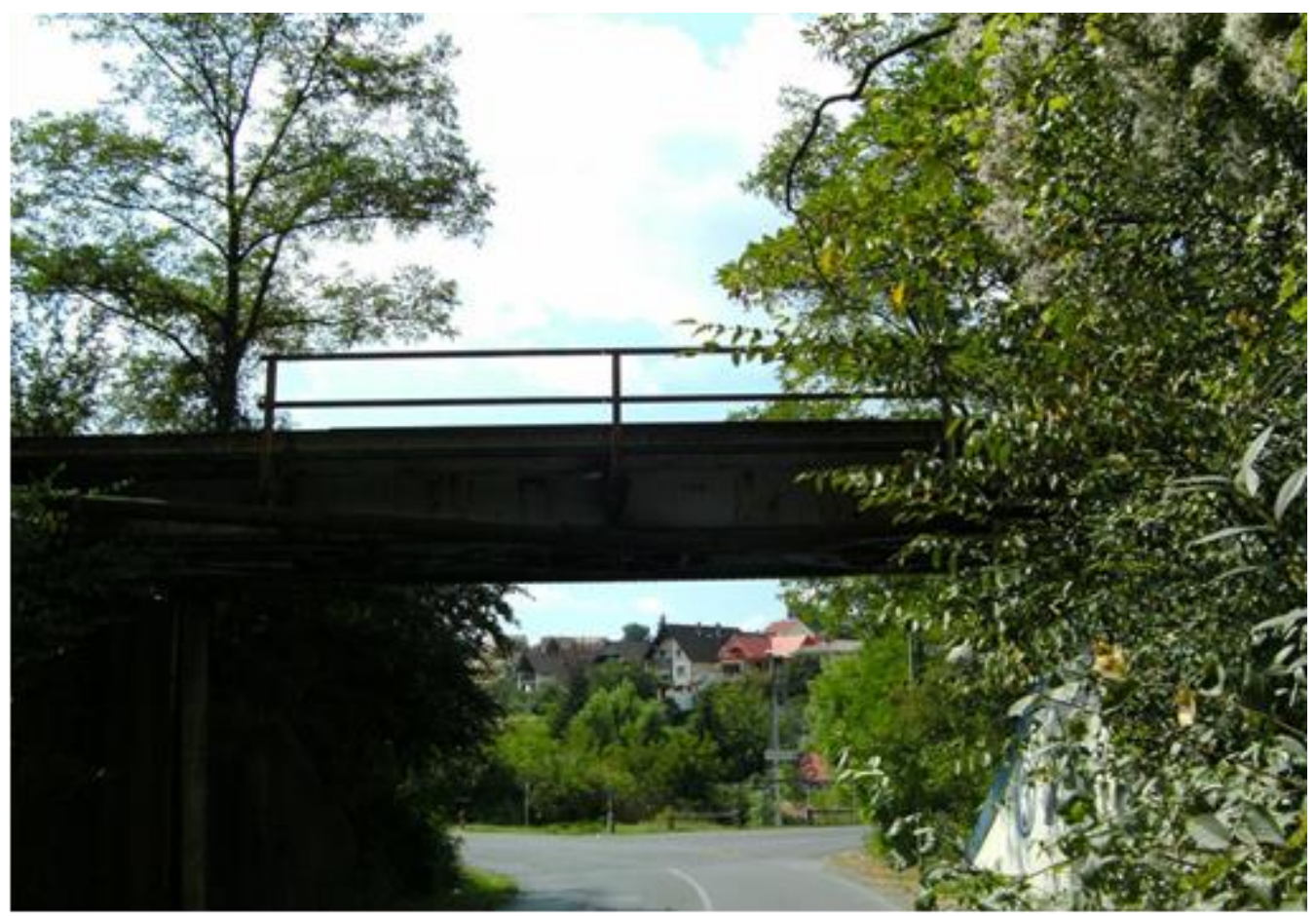

Fotó: Uherkovich Péter, 2004. Uherkovich Péter magángyüjteménye 
9. sz. melléklet: Egykori vasúti felvigyázólakás a Szabolcsfalusi vasút nyomvonalán, az egykori vasút-közút kereszteződésben a Szabolcsi úton

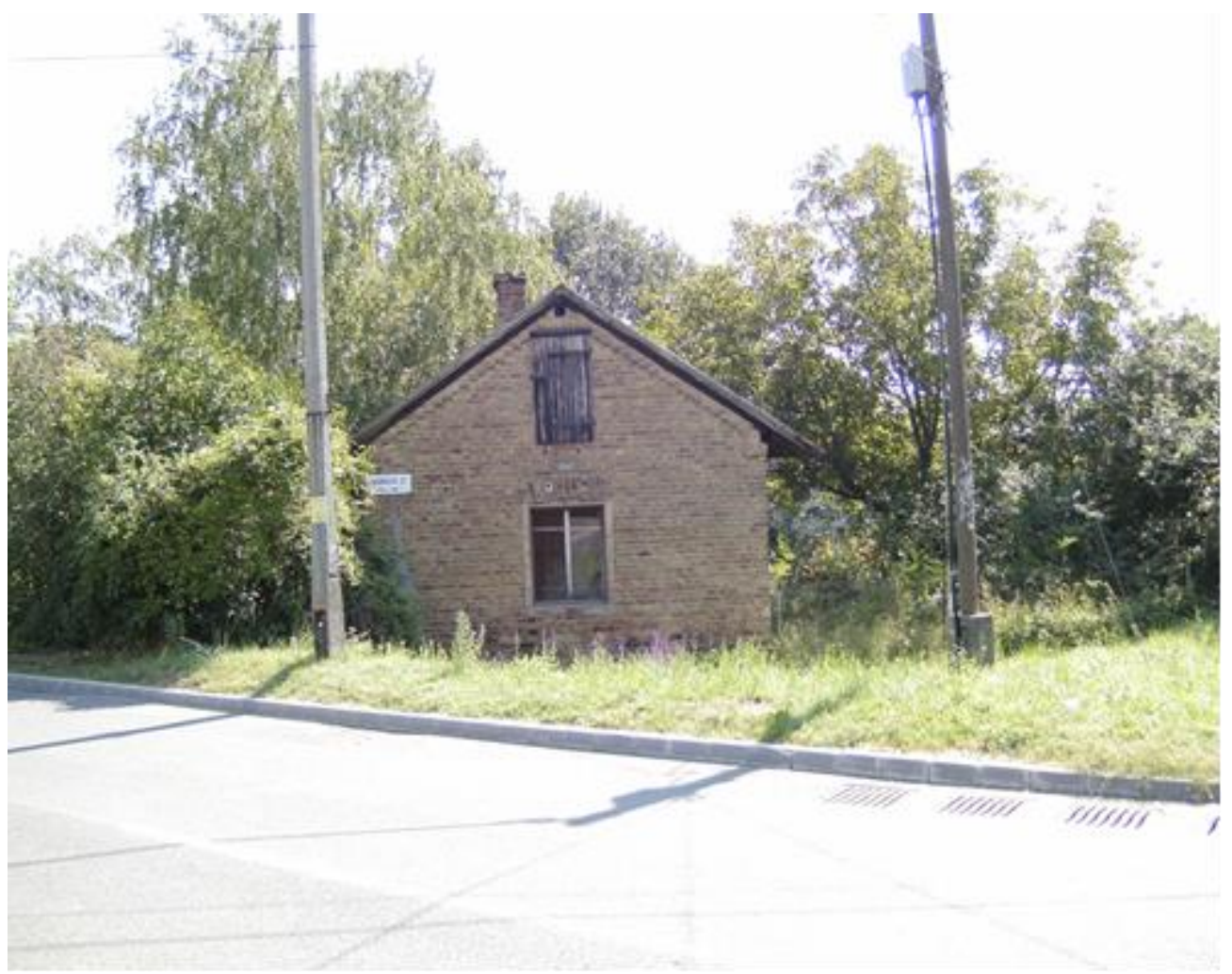

Fotó: Bércesi Richárd, 2010.

10. sz. melléklet: Az egykori mozdonyremíz épülete (1911-), (Pécsújhegy)

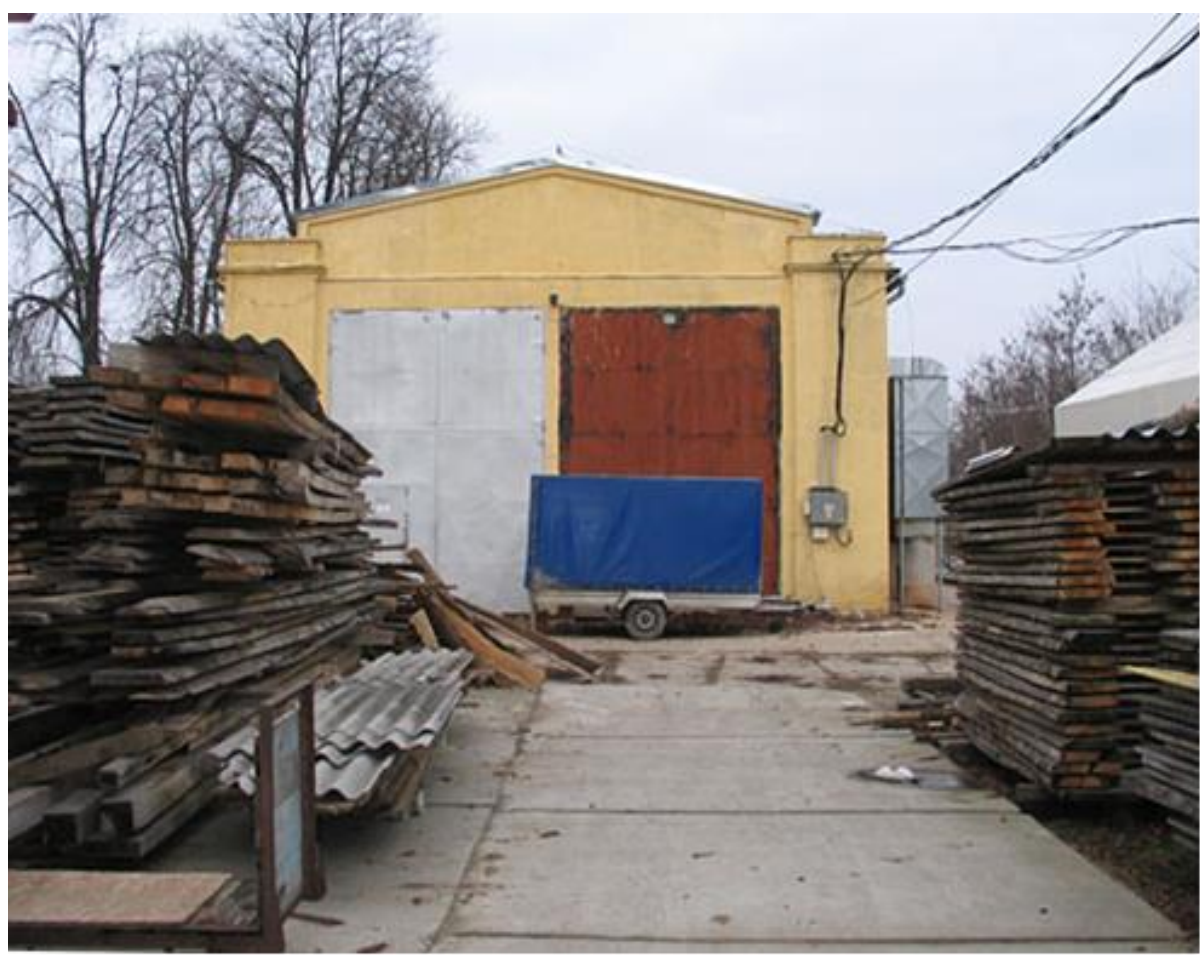

Fotó: Löffler Péter, 2008. A Pécsi Bányásztörténeti Alapítvány hagyatéka, Janus Pannonius Múzeum Pécsi Várostörténeti Múzeum 
11. sz. melléklet: Az egykori mozdonyremíz épülete II. (Pécsújhegy)

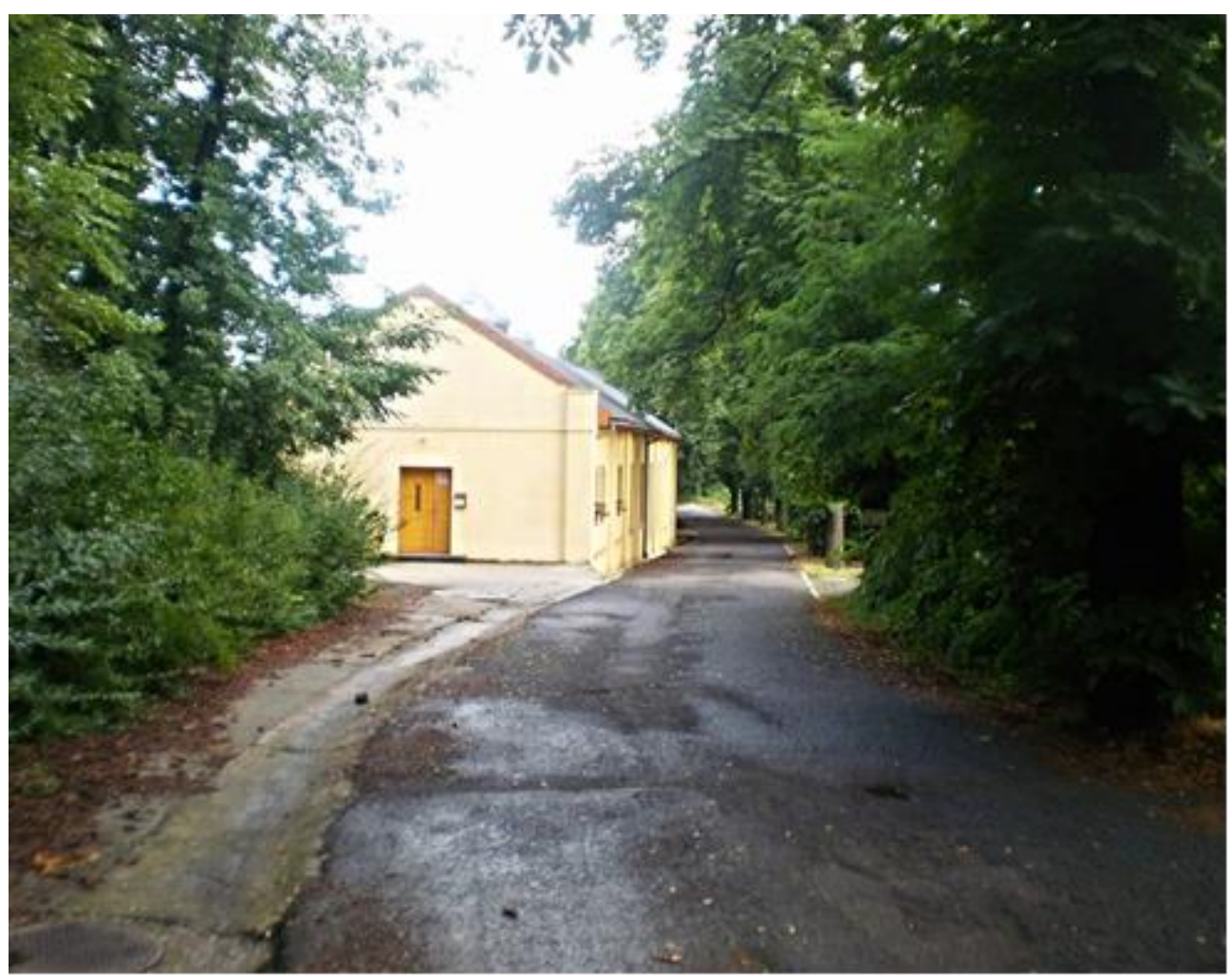

Fotó: Bércesi Richárd, 2014.

12. sz. melléklet: A DGT Pécs-üszögi helyi kirendeltsége, majd a pécsi bányavidék kihelyezett, központi irodaépülete (1923-). Pécsújhegy

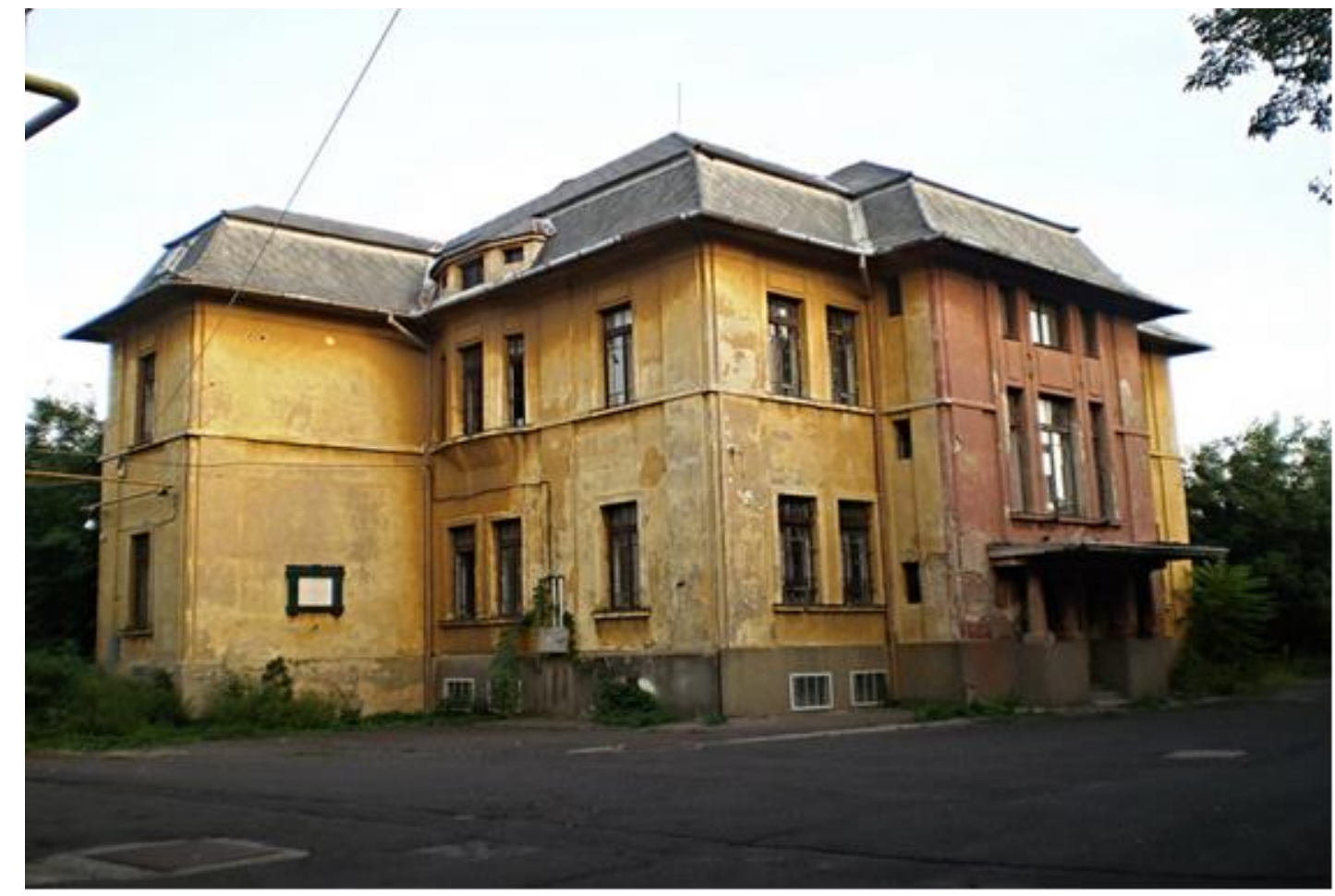

Fotó: Löffler Péter, 2017. A Pécsi Bányásztörténeti Alapítvány hagyatéka, Janus Pannonius Múzeum Pécsi Várostörténeti Múzeum 


\section{3. sz. melléklet: A meszespusztai lakótelep (1922-) napjainkban}

Gábor Áron utca

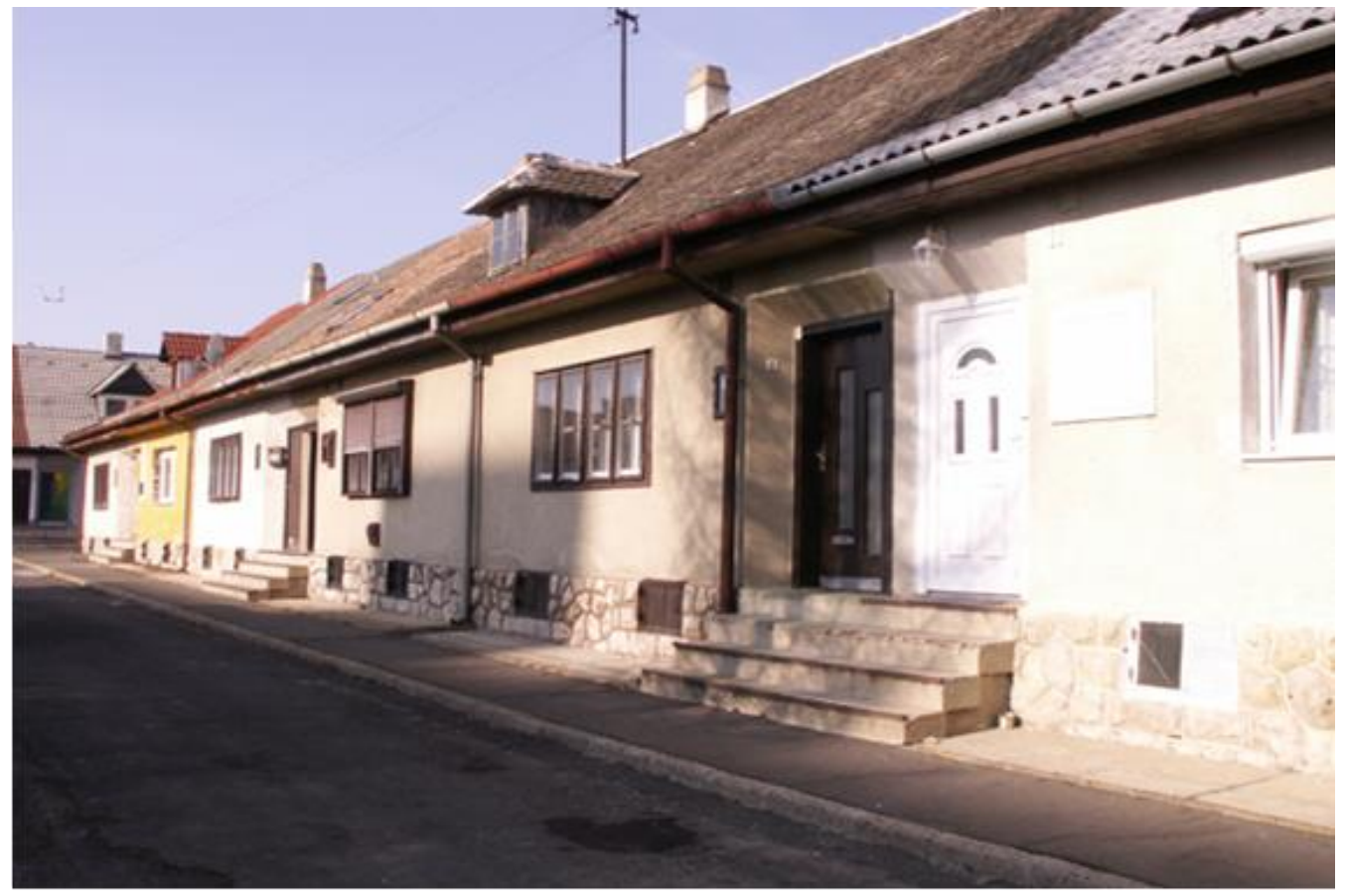

Fotó: Löffler Péter, 2017. A Pécsi Bányásztörténeti Alapítvány hagyatéka, Janus Pannonius Múzeum Pécsi Várostörténeti Múzeum

\section{4. sz. melléklet: A fehérhegyi víztorony (1925-)}

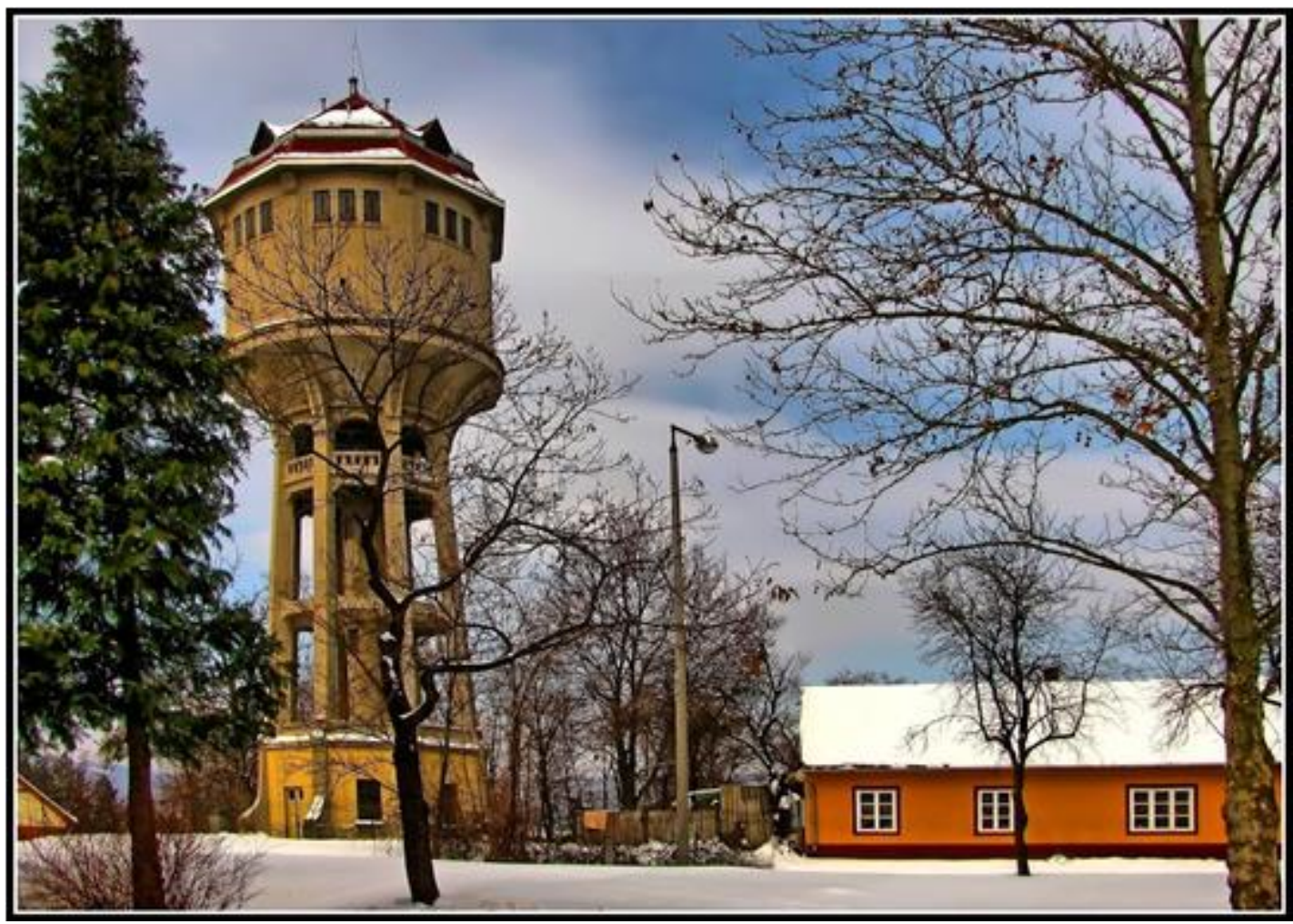

Fotó: Löffler Péter, 2008. A Pécsi Bányásztörténeti Alapítvány hagyatéka, Janus Pannonius Múzeum Pécsi Várostörténeti Múzeum 


\section{5. sz. melléklet: I. (Szent) István-akna (1925-)}

Mecsekszabolcs

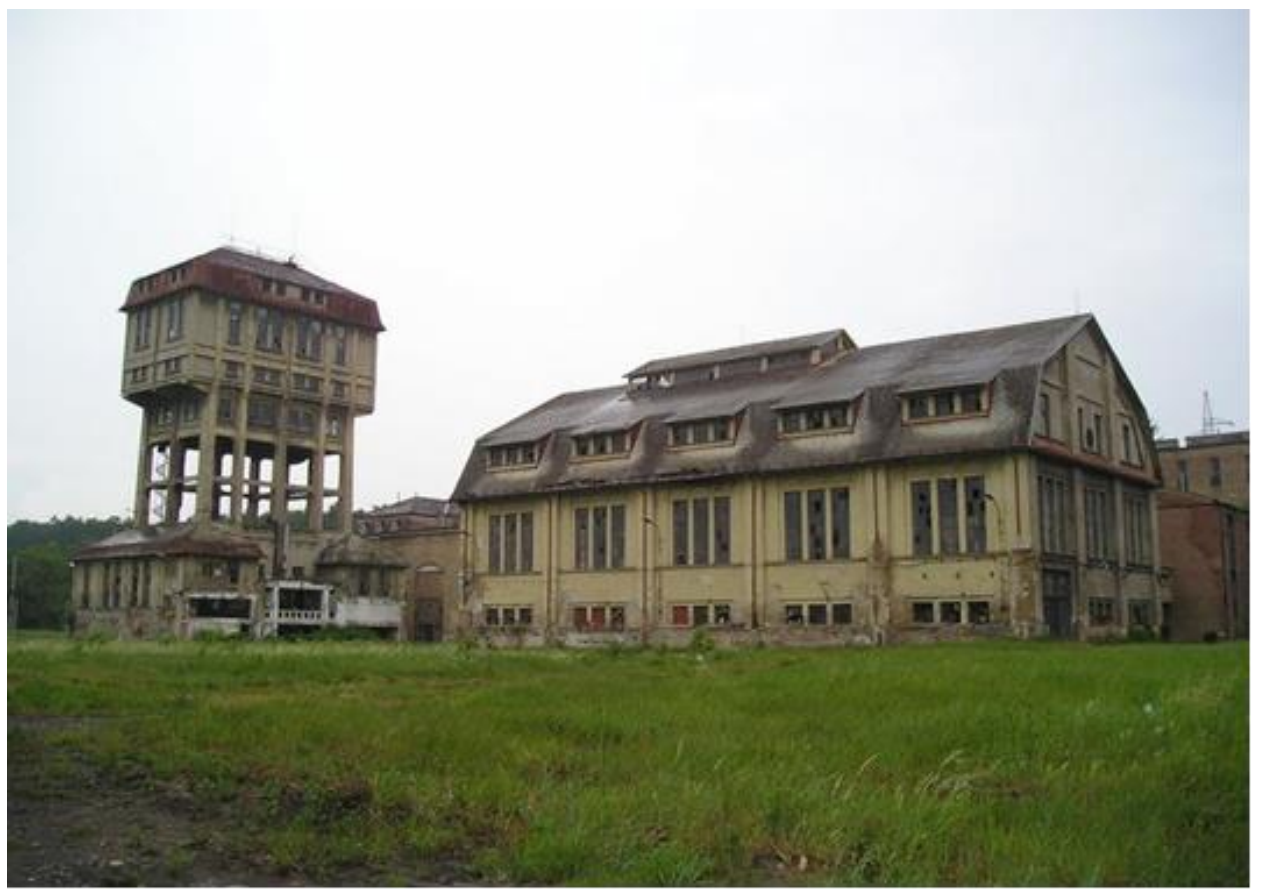

Fotó: Löffler Péter, 2015. A Pécsi Bányásztörténeti Alapítvány hagyatéka, Janus Pannonius Múzeum Pécsi Várostörténeti Múzeum

\section{6. sz. melléklet: Gróf Széchenyi István-akna (1926-)}

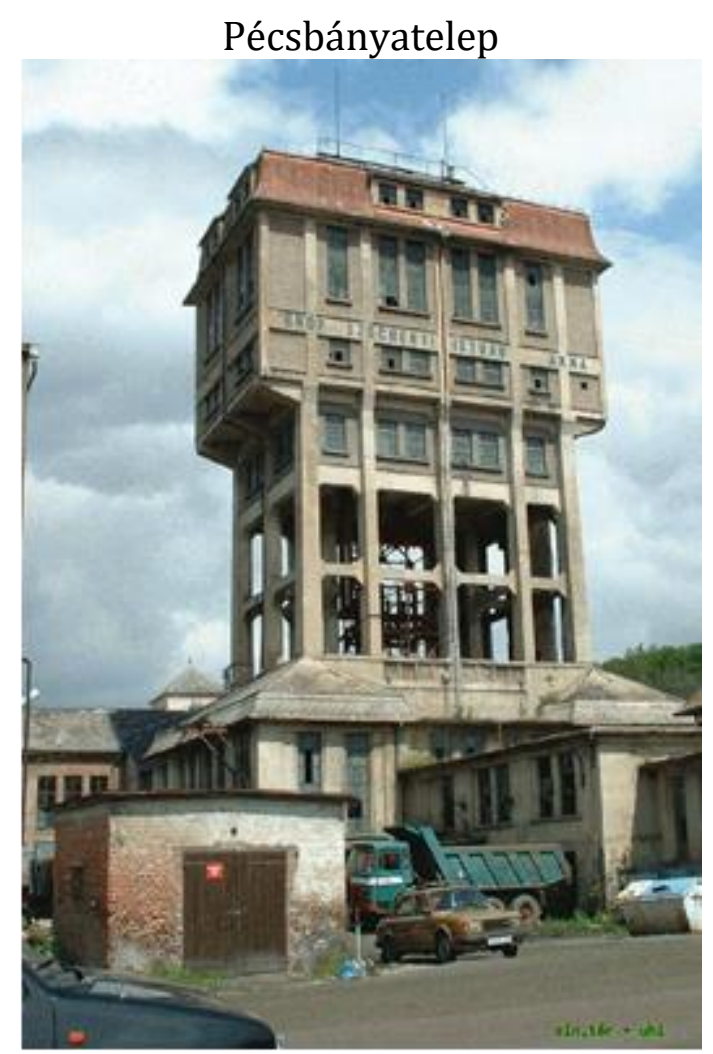

Fotó: Uherkovich Péter, 2004. Uherkovich Péter magángyüjteménye 
17. sz. melléklet: A Mohács-Pécsi Vasút és a Pécsbányatelepi vasút közös emléktáblája a Zsolnay Vilmos úti egykori vasúti átjáróban, a Dél-Dunántúl első, vasút-közút kereszteződésében

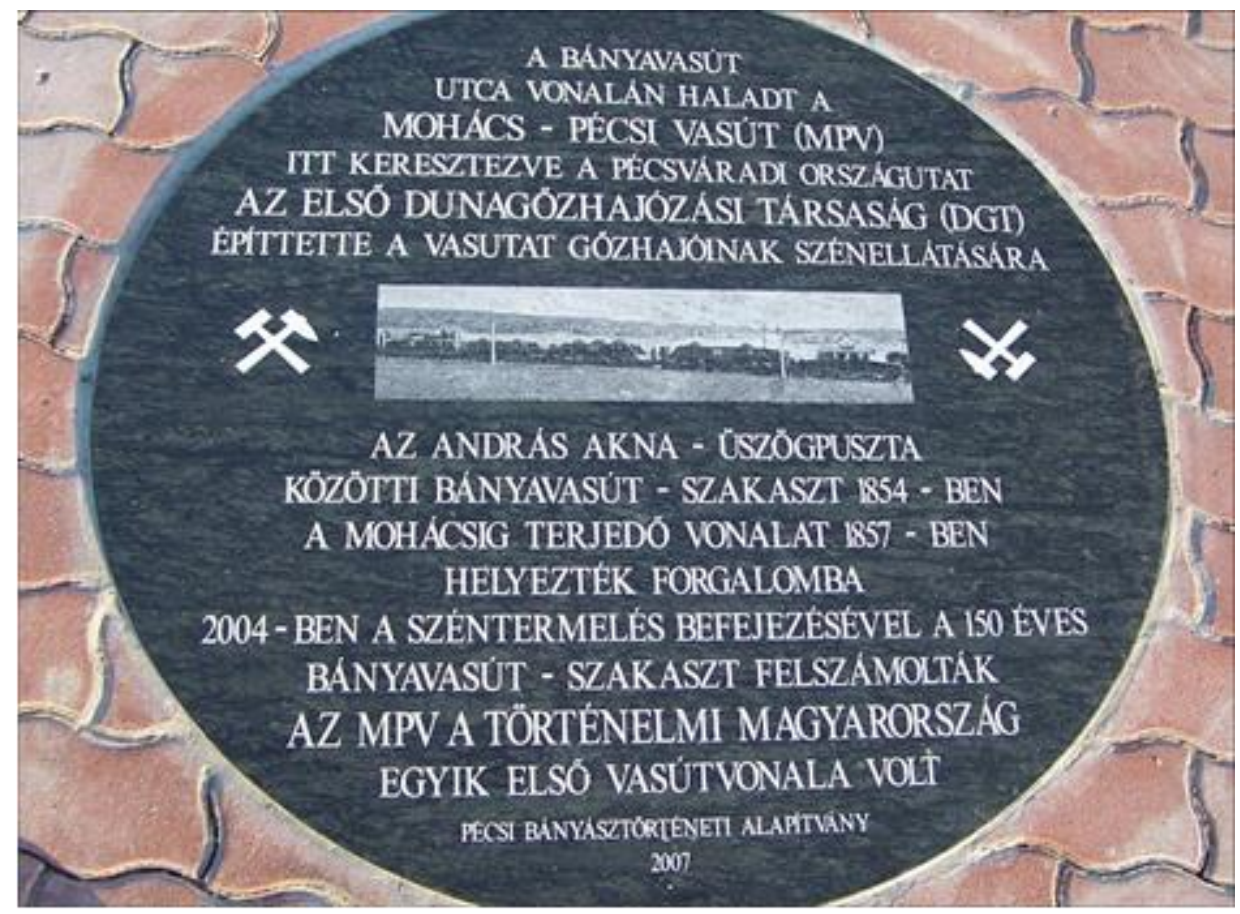

Fotó: Bércesi Richárd, 2012. március 1

18. sz. melléklet: A Mohács-Pécsi Vasút emléktáblája az egykori üzemvezetőség falán

Pécs, Belváros, Mária utca 7.

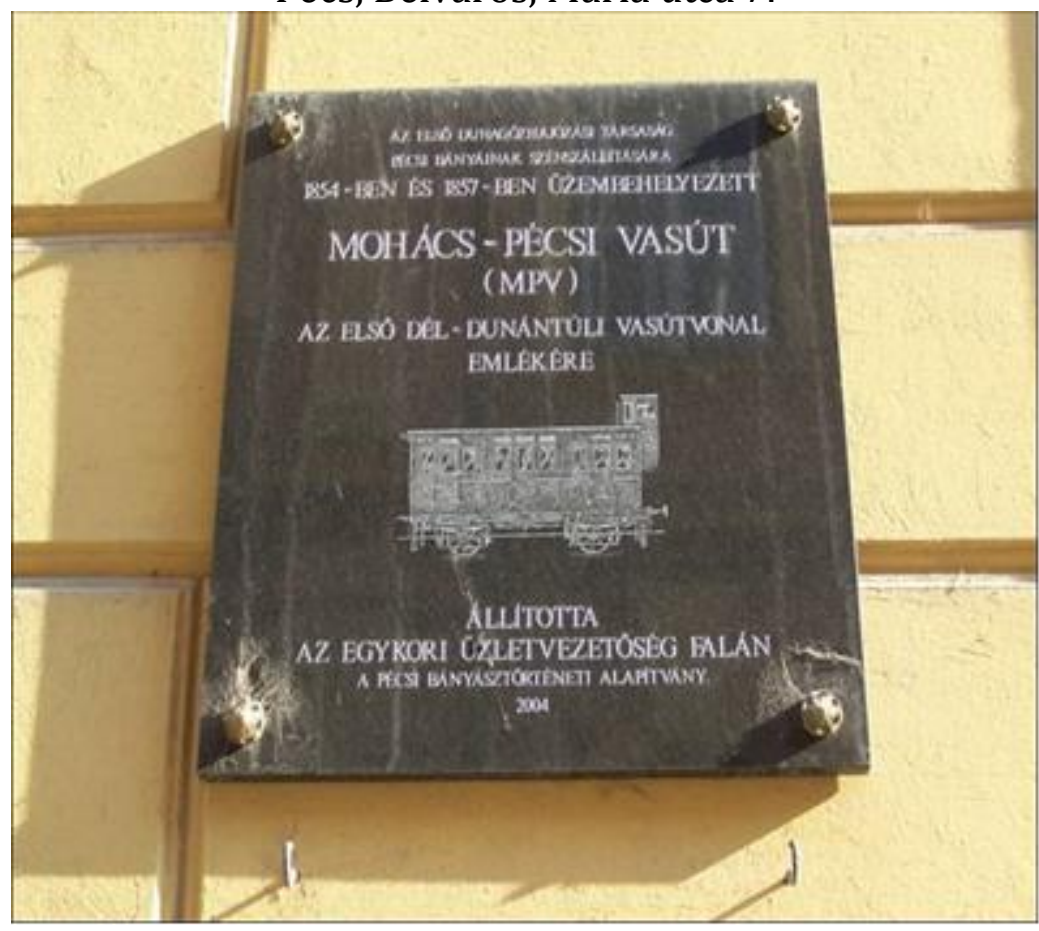

Fotó: Bércesi Richárd, 2012 
19. sz. melléklet: A Mecsekszabolcsi/Szabolcsfalusi vasút (1873-1963) és a Szabolcsi légakna közös emlékköve Mecsekszabolcson a Béke-akna és György-akna felé vezető, egykori vasúti elágazónál

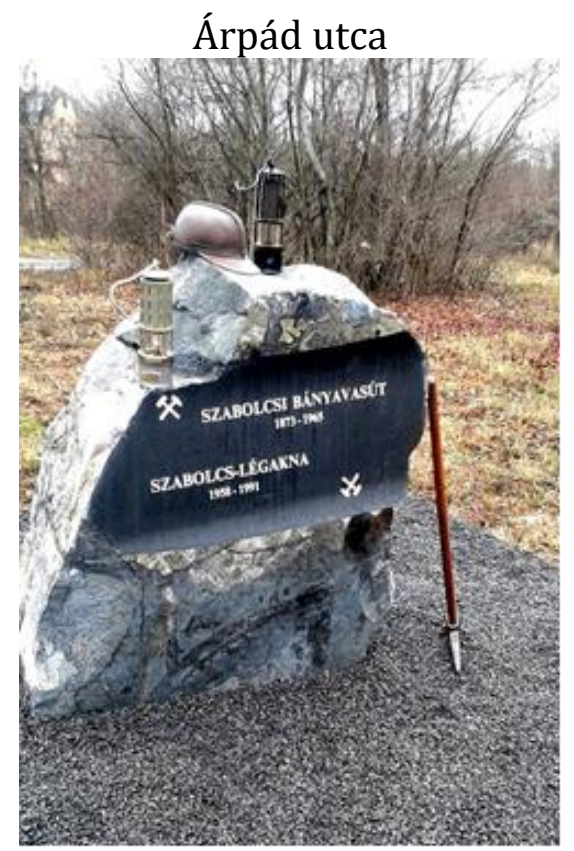

Fotó: Bércesi Richárd, 2019

20. sz. melléklet: A DGT egykori Pécsújhegyi üzemének emléktáblája a volt főbejárat közelében

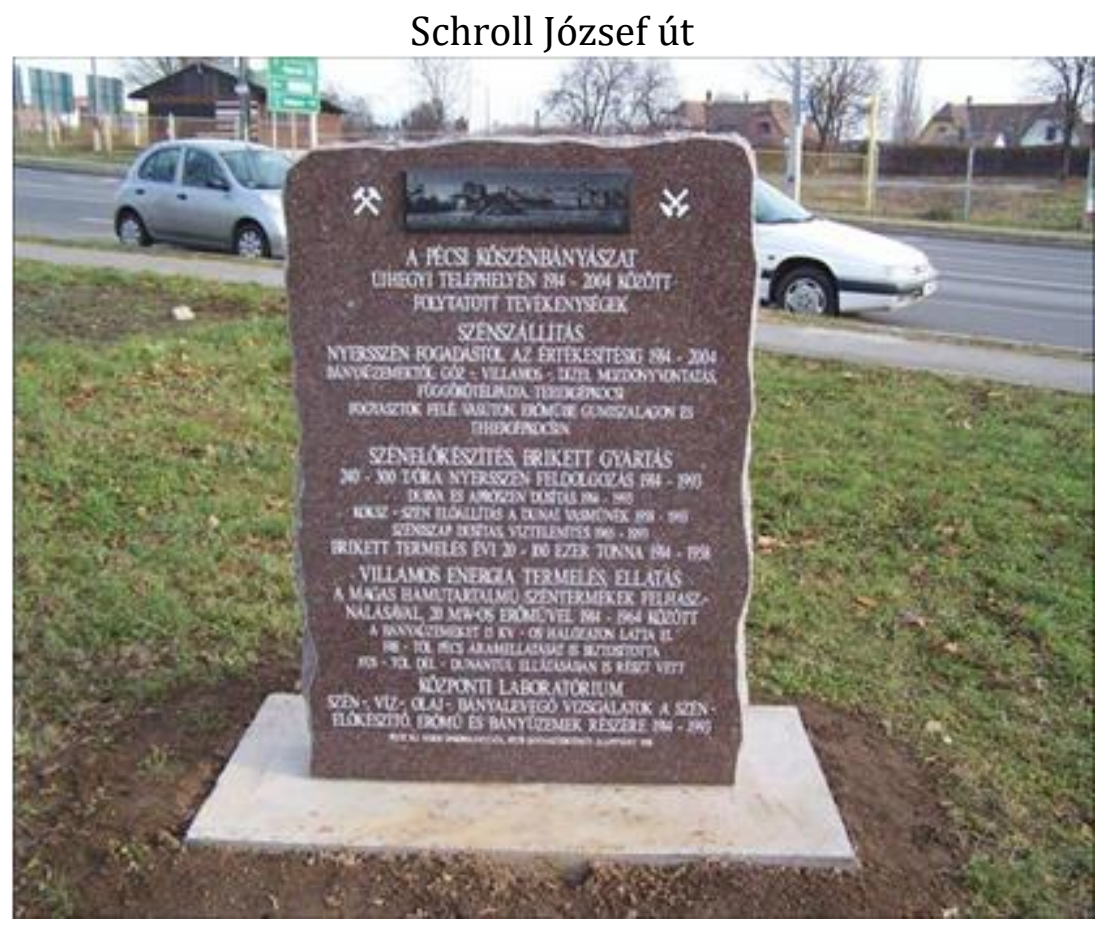

Fotó: Bércesi Richárd, 2012. 
21. sz. melléklet: A Pécsi Bányamanók díszsorfala a szeptember első vasárnapján tartott bányásznapi megemlékezésen

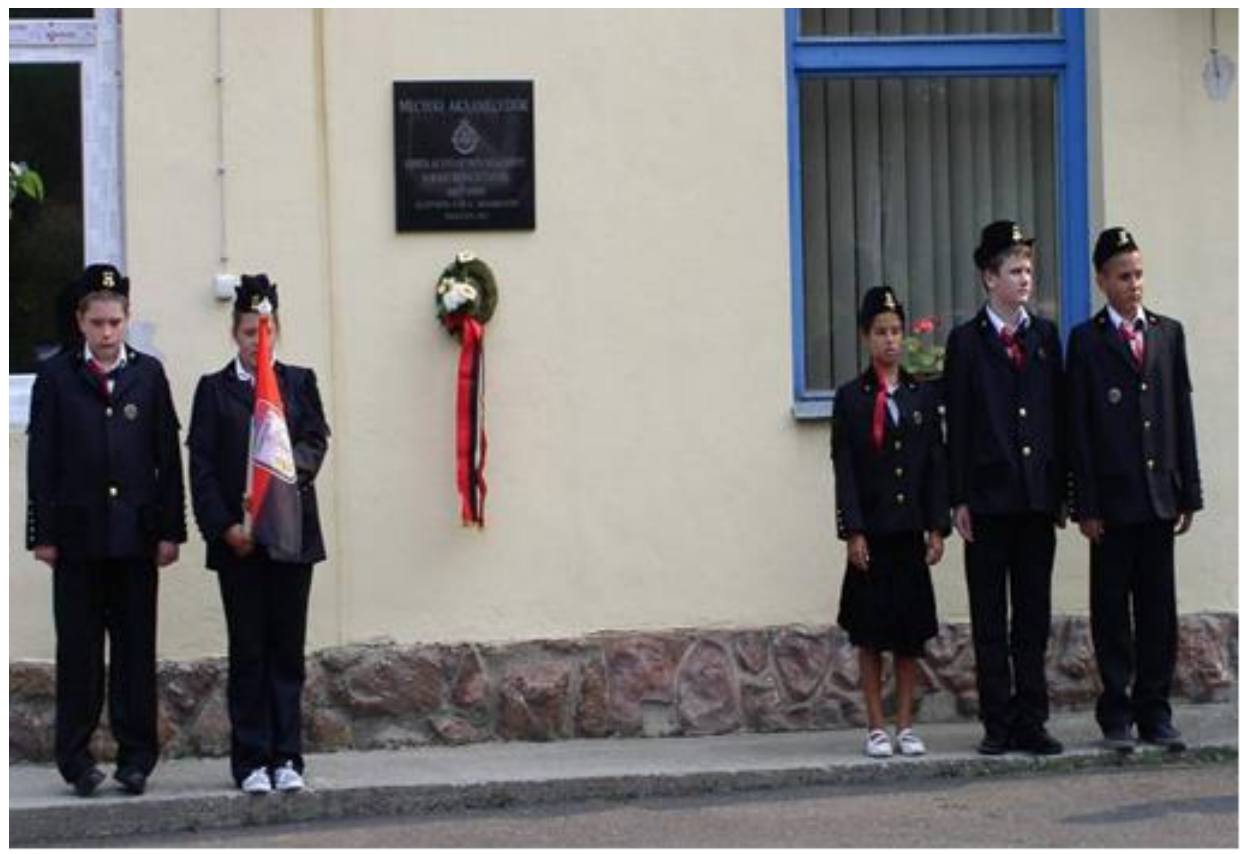

Fotó: Löffler Péter, 2017. A Pécsi Bányásztörténeti Alapítvány hagyatéka, Janus Pannonius Múzeum Pécsi Várostörténeti Múzeum

22. sz. melléklet: Az osztrák-magyar vegyesvállalat, az Első Dunagőzhajózási Társaság (DGT)/Erste Donau Dampschifffahrts-Gesellschaft (DDSG) logója a cég magyar és osztrák rövidítésével a cég alapításának 100. évfordulójára az alkalmazottak számára kiadott emlékkitűzőn (1929)

A Pécsi Bányásztörténeti Alapítvány hagyatéka, Janus Pannonius Múzeum Pécsi Várostörténeti Múzeum

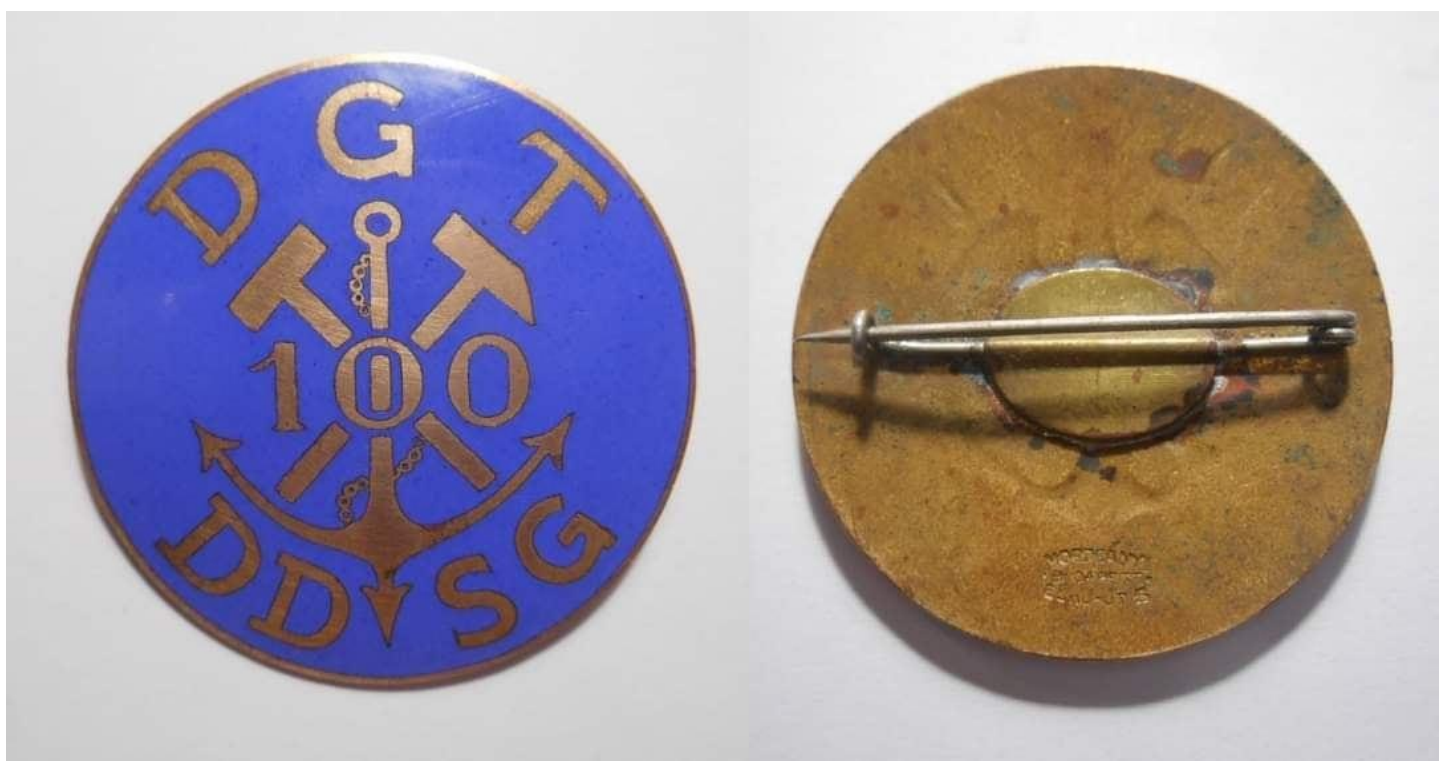

